\title{
Dynamical Structure of Extreme Floods in the U.S. Midwest and the United Kingdom
}

\author{
JENNIFER NAKAMURA \\ Division of Ocean and Climate Physics, Lamont-Doherty Earth Observatory of Columbia University, Palisades, New York \\ UPMANU LALL \\ Department of Earth and Environmental Engineering, Columbia University, New York, New York \\ YOCHANAN KUSHNIR \\ Division of Ocean and Climate Physics, Lamont-Doherty Earth Observatory of Columbia University, Palisades, New York \\ ANDREW W. ROBERTSON \\ International Research Institute for Climate and Society, Columbia University, Palisades, New York \\ RICHARD SEAGER \\ Division of Ocean and Climate Physics, Lamont-Doherty Earth Observatory of Columbia University, Palisades, New York
}

(Manuscript received 20 April 2012, in final form 17 September 2012)

\begin{abstract}
Twenty extreme spring floods that occurred in the Ohio basin between 1901 and 2008, identified from daily river discharge data, are investigated and compared to the April 2011 Ohio River flood event. Composites of synoptic fields for the flood events show that all of these floods are associated with a similar pattern of sustained advection of low-level moisture and warm air from the tropical Atlantic Ocean and the Gulf of Mexico. The typical flow conditions are governed by an anomalous semistationary ridge, situated east of the U.S. East Coast, that steers the moisture and converges it into the Ohio River valley. Significantly, the moisture path common to all of the 20 cases studied here as well as the case of April 2011 is distinctly different from the normal path of Atlantic moisture during spring, which occurs farther west. It is shown further that the Ohio basin moisture convergence responsible for the floods is caused primarily by the atmospheric circulation anomaly advecting the climatological mean moisture field. Transport and related convergence due to the covariance between moisture anomalies and circulation anomalies are of secondary but nonnegligible importance. The importance of atmospheric circulation anomalies to floods is confirmed by conducting a similar analysis for a series of winter floods on the river Eden in northwest England.
\end{abstract}

\section{Introduction}

Floods account for a large fraction of losses due to natural hazards (Federal Interagency Floodplain Management Task Force 1992). The combination of large air thermal contrasts, larger amounts of water vapor in warmer air, saturated soils, frozen ground, and snowmelt

Corresponding author address: Jennifer Nakamura, Division of Ocean and Climate Physics, Lamont-Doherty Earth Observatory of Columbia University, 103F Oceanography, 61 Route 9W, P.O. Box 1000, Palisades, NY 10964-8000.

E-mail: nakamura_jennifer@yahoo.com make spring the season with the greatest flooding potential in most of the United States (Hirschboeck 1991). The subject of our study, the Ohio River, is the largest tributary, by volume, of the Mississippi River. The March 1913 flood in the Ohio River basin tops the list of significant regional floods in the United States in the twentieth century in terms of number of lives lost and property damage (Perry 2000). The April 2011 flood event that contributed to subsequent lower Mississippi River floods was another major event and ranks in the top five spring events in the 85-yr record at the East Fork of the White River in Shoals, Indiana, a tributary of the Ohio River. 
It has been recognized that, especially for larger river basins, a link between an oceanic moisture source and local precipitation is likely necessary for generating the extreme precipitation associated with a large regional flood (Hirschboeck 1991). Antecedent soil moisture or snowmelt may also contribute to enhanced flood potential but may in turn be the consequence of prior moisture transport into the basin from the same oceanic source. Thus, for extreme floods, the large-scale meteorological conditions associated with organized transport of moisture from oceanic sources to a continental region are likely to be important. The atmospheric flow anomalies associated with some major floods have been shown to be predictable to some extent in the weather forecast context. Whether they are predictable, in a probabilistic sense, on longer, seasonal time scales, using either dynamical or statistical models, is not yet clear. Such an assessment requires an understanding of the underlying physics, which is what we attempt here.

Hirschboeck (1991) laid out a classification for the climatic context of floods, identifying the key seasons and the general pathways of atmospheric moisture transport associated with large regional floods. However, to date there has been only a limited quantitative application of her ideas to the problem of understanding the recurrence of floods and predicting when and where they will occur. The concept of "atmospheric rivers" (Zhu and Newell 1994, 1998) and their connection to flood events (Ralph et al. 2006; Neiman et al. 2011) is a notable advance in this direction. The term atmospheric river (AR), coined by Zhu and Newell (1994), refers to the long (planetary scale) filaments of atmospheric moisture seen in the vertically integrated water vapor field and that are associated with fast-moving atmospheric flows. These atmospheric features are transient and not spatially fixed and can be best seen in daily satellite picture and weather analyses (Zhu and Newell 1998). Much of the analysis associated with these phenomena was focused on Pacific Ocean cases that carry moisture to the western United States, the so-called Pineapple Express because of the link back to the Hawaii region of the subtropical Pacific (Dettinger 2011; Dettinger et al. 2011). Dirmeyer and Kinter (2009) identified similar features carrying moisture from the tropical Atlantic into the U.S. Midwest in May-July and coined the term "Maya Express." They found that this feature is due to a strengthening or westward shift of the Atlantic Subtropical Ridge. These authors also state that large-scale flooding over the U.S. Midwest is not local but part of a large-scale circulation change connecting the tropics and midlatitudes (Dirmeyer and Kinter 2010). Moore et al. (2012) examined a case study in which ARs from both the eastern tropical Pacific and Caribbean Sea lead to the formation of mesoscale convective systems and subsequent flooding in Tennessee and Kentucky. In a recent analysis focused on the Atlantic basin, Lavers et al. (2011) showed ARs to be present during the top 10 flood events since 1970 for several river basins in Britain.

While much flood-related research has focused on anomalous moisture transports, it is also the case that the climatological moisture transport occurs in specific regions. The climatology of tropical moisture export (TME) assembled by Knippertz and Wernli (2010) provides a framework for understanding the pattern of large moisture advection paths out of the Northern Hemisphere tropics. North American tropical flows in the spring include the Great Plains (GP) TME between the Rockies and the Appalachians and the Gulf Stream (GS) TME to the east of the Appalachians. In spring at $35^{\circ} \mathrm{N}$ Knippertz and Wernli (2010) found the GP and GS TME well separated, both concentrated predominately below $600 \mathrm{hPa}$, with the strongest GP TME at approximately $860 \mathrm{hPa}$ and the middle of the GS TME higher at about $780 \mathrm{hPa}$. In winter at $50^{\circ} \mathrm{N}$ GS trajectories show strong ascents into the midtroposphere and the tracks shift eastward by as much as $20^{\circ}$ longitude (Knippertz and Wernli 2010). At this latitude band in winter, GS tropical moisture export can reach the northern European coast and Great Britain.

In this paper we examine the meteorological context of major Ohio River basin floods (identified as a 10-yr return period in annual maxima of streamflow) and examine the conditions that led to the flooding in April 2011 in this context. We demonstrate that these floods are associated with a recurrent type of persistent, anomalous large-scale circulation pattern that is responsible for conditions leading to atmospheric moisture flows into, and convergence over, the basin and heavy precipitation during each of the 20 large spring (March-May) floods identified between 1901 and 2008. We then show that the April 2011 Ohio River flood exhibited very similar meteorological conditions and multiday evolution as the composite of the previous 20 major floods, thus confirming the unique meteorological state that leads to extreme floods in the Ohio River basin.

We further demonstrate that the apparent atmospheric rivers and floods are caused primarily by circulation anomalies advecting and converging the background mean climatological moisture field. This is also found to be the case in the very different meteorological environment of winter floods in Great Britain (Lavers et al. 2011). Both case studies illustrate the importance of atmospheric circulation variability on daily to seasonal time scales in causing extreme floods. 
TABLE 1. Date 10-yr flood threshold is exceeded at gauge station and USGS station identifier.

\begin{tabular}{ll}
\hline \multicolumn{1}{c}{ Date } & \multicolumn{1}{c}{ Station } \\
\hline 21 Apr 1901 & 03193000 \\
23 May 1901 & 03193000 \\
1 Mar 1902 & 03193000 \\
24 Mar 1903 & 03193000 \\
28 Mar 1913 & 03193000 \\
20 Mar 1933 & 03234500,03377500 \\
14 May 1933 & 03234500 \\
5 Mar 1934 & 03193000 \\
17 Apr 1939 & 03234500 \\
20 Apr 1940 & 03234500 \\
20 Mar 1943 & 03234500 \\
18 May 1943 & $03335500,03360500,03377500$ \\
7 Mar 1945 & 03234500,03373500 \\
22 Mar 1945 & 03234500 \\
14 Apr 1948 & 03234500 \\
13 May 1961 & $03360500,03373500,03374000,03377500$ \\
5 Mar 1963 & 03234500 \\
10 Mar 1964 & 03234500 \\
25 May 1968 & 03234500 \\
4 May 1996 & 03373500 \\
\hline
\end{tabular}

\section{Data and methods}

Twenty Ohio basin floods that occurred prior to the April 2011 event were selected by analyzing daily river discharge data from seven gauging stations associated with subbasins of the Ohio River larger than $10^{3} \mathrm{~km}^{2}$. The events and stations are listed in Tables 1 and 2 . These seven stations were originally identified as part of the Hydro-Climatic Data Network (HCDN) of the U.S. Geological Survey (USGS), and their data are reportedly free of regulation and diversion. For each station, events where the peak flow exceeded the 10-yr flood during the spring (March-May) season were identified for years 1901-2008.

The 10-yr flood event at each station was computed according to the U.S. Interagency Advisory Committee on Water Data publication "Guidelines for Determining Flood Flow Frequency," Bulletin 17-B of the Hydrology Subcommittee, with the addition of digitized generalized skew values extracted from the program PeakFQ (http://water.usgs.gov/software/PeakFQ). The assumption is that the flood information is a reliable representation of random homogeneous events. This includes climatic time invariance, floods as independent events, no watershed changes, similar types of events, and good data quality. Selection of HCDN stations by the USGS was made to meet as many of the above assumptions as possible, resulting in many fewer stations than the original USGS data.

Once the 10-yr flood frequency was computed for every station using water-year (October-September) annual peak maximum flow, daily data were processed to identify dates when the peak flow exceeded the 10-yr threshold. Most flood events occurred at one station, but a few occurred simultaneously at several. The earliest flood date was selected for a multiple subbasin flooding event. Some flooding events last a day and some weeks. To analyze preflood conditions, day 0 is defined as the first day of a possible series of flooding days.

Day 0 for comparison floods in Great Britain are the eight floods identified in Lavers et al. (2011) that occurred before 2008 on the river Eden at Temple Sowerby in northwest England. These floods were found by taking the top river flow dates from the U.K. National River Flow Archive of the winter half-year (OctoberMarch) daily mean maximum. Temple Sowerby is the largest subbasin in the Upper Eden catchment, with an area of $616.4 \mathrm{~km}^{2}$, and the rainfall regime is predominantly frontal with a maximum in the winter (Ockenden and Chappell 2011).

The distribution of all flooding events for gauged Ohio River subbasins greater than $10^{3} \mathrm{~km}^{2}$ shows that they occur year round, with a median in February and a mean in mid March. However, the distribution is heavily positively skewed toward the spring months with the 75th percentile at about 10 May. A third of the extreme floods occur in spring, the largest percent of any of the seasons.

Given that most of the floods exceeding the nominal 10 -yr exceedance level occurred in the first half of the twentieth century, we use daily averaged 20th Century Reanalysis V2 data (20CR) (Compo et al. 2011) as the principal source of atmospheric data for the historical analysis for both the Ohio and Eden basins. The original

TABLE 2. Attributes of the seven selected WMO stations in the Ohio basin

\begin{tabular}{llllcrr}
\hline \hline IWMO & River & \multicolumn{1}{c}{ City } & \multicolumn{1}{c}{ State } & Lat $\left({ }^{\circ} \mathrm{N}\right)$ & Lon $\left({ }^{\circ} \mathrm{W}\right)$ & Basin $\left(\mathrm{km}^{2}\right)$ \\
\hline 03193000 & Kanawha & Kanawha Falls & West Virginia & 38.08 & 81.13 & 21681 \\
03234500 & Scioto & Higby & Ohio & 39.12 & 82.52 & 13289 \\
03335500 & Wabash & Lafayette & Indiana & 40.25 & 86.53 & 18821 \\
03360500 & White & Newberry & Indiana & 38.55 & 87.00 & 12142 \\
03373500 & White & Shoals & Indiana & 38.40 & 86.47 & 12761 \\
03374000 & White & Petersburg & Indiana & 38.30 & 87.17 & 28814 \\
03377500 & Wabash & Mt. Carmel & Illinois & 38.24 & 87.45 & 74164 \\
\hline
\end{tabular}




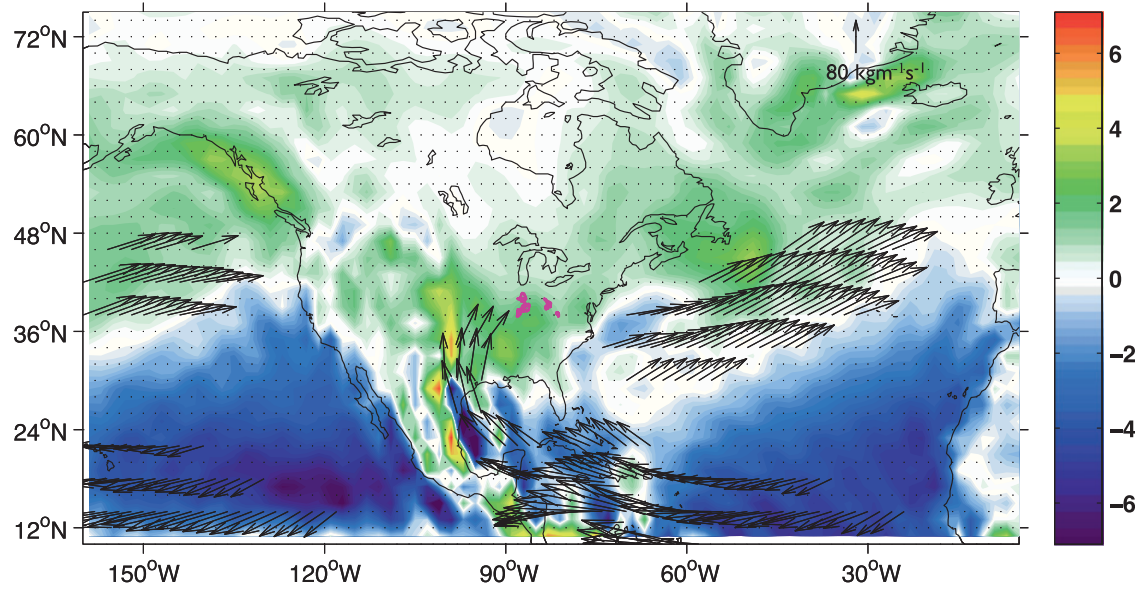

FIG. 1. March-May 1961-90 climatology of vertically integrated surface-600 hPa moisture flux $\left(\mathrm{kg} \mathrm{m}^{-1} \mathrm{~s}^{-1}\right)$ (strongest $20 \%$ of values shown as arrows) and moisture convergence $\left(\mathrm{mm} \mathrm{day}^{-1}\right)$ (colors) with basin outlines in dark pink.

20CR 6-hourly output is provided by the NOAA Earth System Research Laboratory in Boulder, Colorado (http://www.esrl.noaa.gov/psd/). The 20CR is derived by driving the April 2008 experimental version of the National Centers for Environmental Prediction (NCEP) Global Forecast System (GFS) with observed sea surface temperature boundary conditions and assimilating historical surface pressure observations only (Compo et al. 2011). The 20CR is a new product that is rapidly being recognized as a source of meteorological data with high temporal resolution, appropriate for diagnostic studies (Emanuel 2010; Compo et al. 2011; Truchelut and Hart 2011; Dole et al. 2011; Barriopedro et al. 2011). Lavers et al. (2011) used the 20CR in their prior study of floods in Great Britain, including those on the river Eden at Temple Sowerby. We tested the robustness of the 20CR results by repeating our analysis using the standard NCEP-National Center for Atmospheric Research Reanalysis (Kistler et al. 2001) for those Ohio River floods that occurred after 1948. The results obtained (not shown) were essentially the same as those obtained with the 20CR.

Historical precipitation data are from the National Climatic Data Center Global Historical Climatology Network (GHCN) daily station data (Vose et al. 1992) gridded over land into $1^{\circ}$ boxes. The April 2011 event data fields are from the daily NCEP-NCAR reanalysis (Kistler et al. 2001).

\section{Results}

\section{a. Ohio basin floods}

Climatological, vertically integrated surface- $-600 \mathrm{hPa}$ moisture flux and its convergence (expressed in $\mathrm{mm}^{\text {day }}{ }^{-1}$ ) for spring illustrate the typical transport pattern and the normal sources and sinks of moisture, respectively (Fig. 1). Moisture sources, shown by low-level divergence of the moisture flux, are present in a broad region of the tropical Atlantic with smaller pockets in the $\mathrm{Ca}$ ribbean Sea and Gulf of Mexico. Vectors of moisture flux show transport of the moisture from the tropical Atlantic, through the Caribbean Sea, and turning northward through the Gulf of Mexico as the low-level flow encounters the leeside trough on the eastern side of the Sierra Madre and Rocky Mountain chains. Moisture sinks, shown as low-level convergence, are present on the high plains just east of the mountains. This climatological pattern is in contrast to the anomalous moisture flux and convergence apparent during an extreme Ohio basin flood (see below).

To show the spatial extent of the precipitation patterns that lead to flooding of the Ohio basin, the precipitation anomaly is plotted in Fig. 2 for the composite of the 20 historical Ohio basin flood events (Fig. 2a) and for the April 2011 event (Fig. 2b), each averaged over the nine days leading up to the floods together with the flood day (designated hereafter as day -9 to 0 ). Both have a positive anomaly over much of the eastern United States and extending into Canada, indicating that these are large-scale events. Weak negative anomalies are seen to the west, over the high plains at the foothills of the Rocky Mountains. The April 2011 event has stronger positive anomalies in the western portion of the basin corresponding heavier flooding in that area-an expected result when a single event is compared with an average of 20 temporally independent events.

Figure 3 shows the composite, vertically integrated surface-600 hPa daily moisture flux and its convergence 
a) MAM 20 Event Composite Days -9 to 0



b) 18-27 Apr 2011

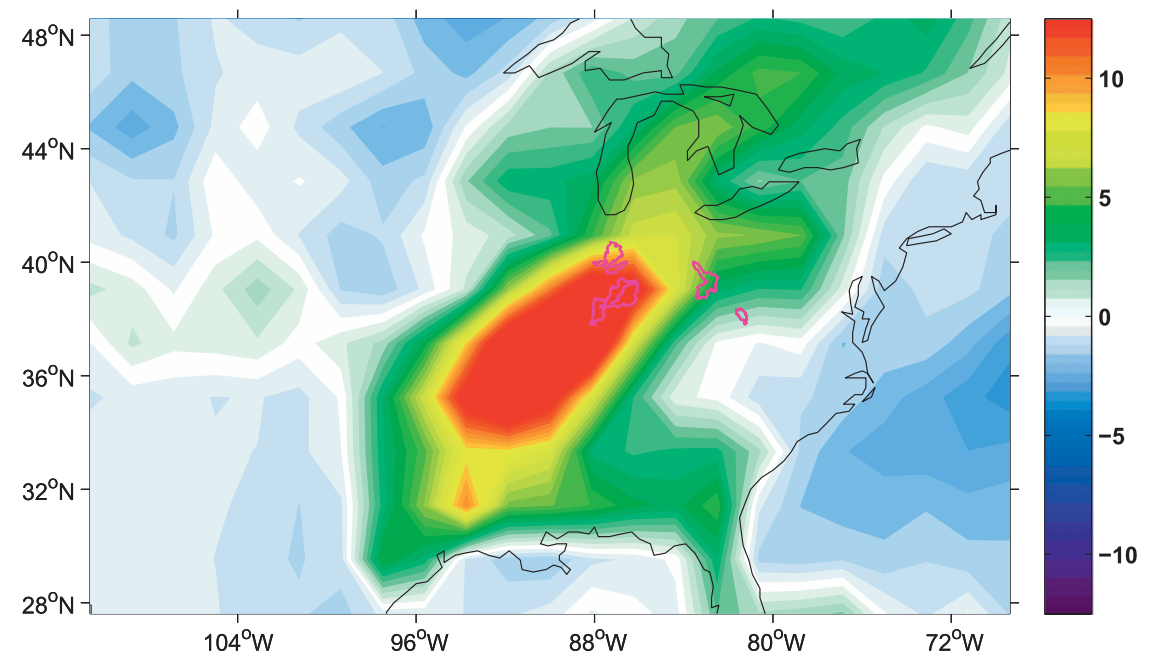

FIG. 2. Precipitation anomaly $\left(\mathrm{mm} \mathrm{day}^{-1}\right)$ of (a) National Climatic Data Center Global Historical Climatology Network daily station data gridded over land into $1^{\circ}$ boxes of the average of 20 historical twentieth-century floods in large river basins in the Ohio valley (basin outlines in dark pink) and (b) NCEP-NCAR reanalysis average of 18-27 Apr 2011.

for the 20 historical Ohio basin flood events (Fig. 3a) and for the April 2011 event (Fig. 3b), averaged over day -9 to 0 of all events, for both the full field (left) and the anomaly relative to a 1961-90 climatology (right). For the total field (Fig. 3, left panels), for both the canonical historical events and the April 2011 event, there is a strikingly similar large-scale pattern of anticyclonic flow of moisture originating in regions of large-scale divergence in the tropical Atlantic, flowing across the Caribbean and Gulf of Mexico, and turning northward into the plains and then northeastward, converging over the Ohio basin. The anomalous moisture flux (Fig. 3, right panels) is concentrated at the western flank of the
Bermuda high, showing southwesterly flow toward the Ohio basin from the Gulf of Mexico and Atlantic Ocean. Departure from the climatological flow is apparent in the divergence anomaly east of the Sierra Madre and Rocky Mountain chains; that is, the convergence has shifted eastward. The precipitation anomalies during these events are associated with anomalous large-scale convergence of moisture that stretches along the entire Mississippi and Ohio River valleys toward the Great Lakes.

To better understand the inherent characteristics of the moisture fluxes and convergence that caused the floods, we decomposed the total daily moisture transport anomaly $\left(Q_{\mathbf{v}}^{\prime}\right)$ into components: 


\section{a) MAM 20 Event Composite Days -9 to 0}
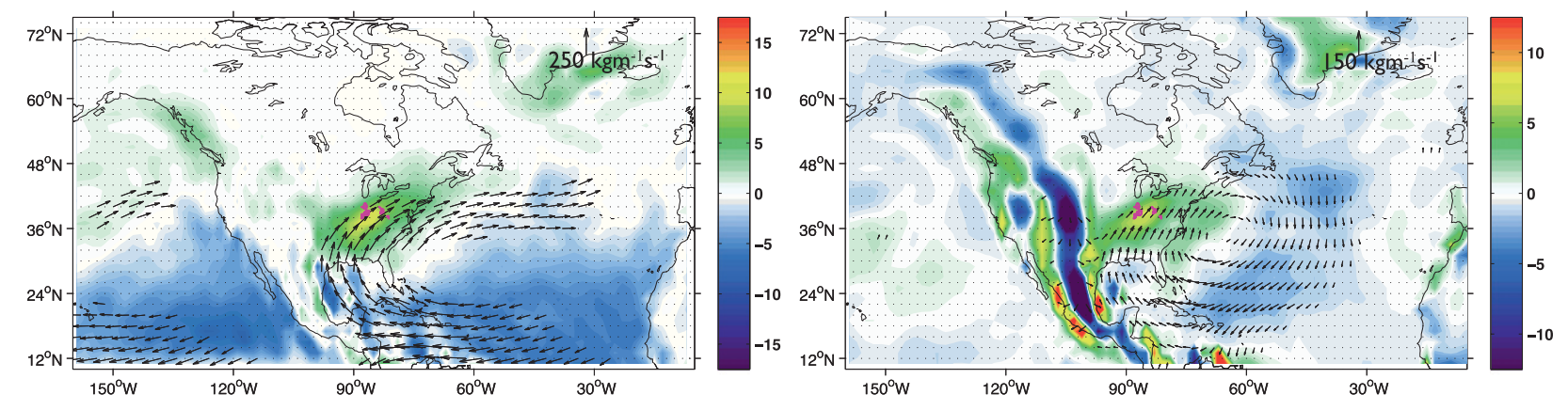

b) 18-27 Apr 2011
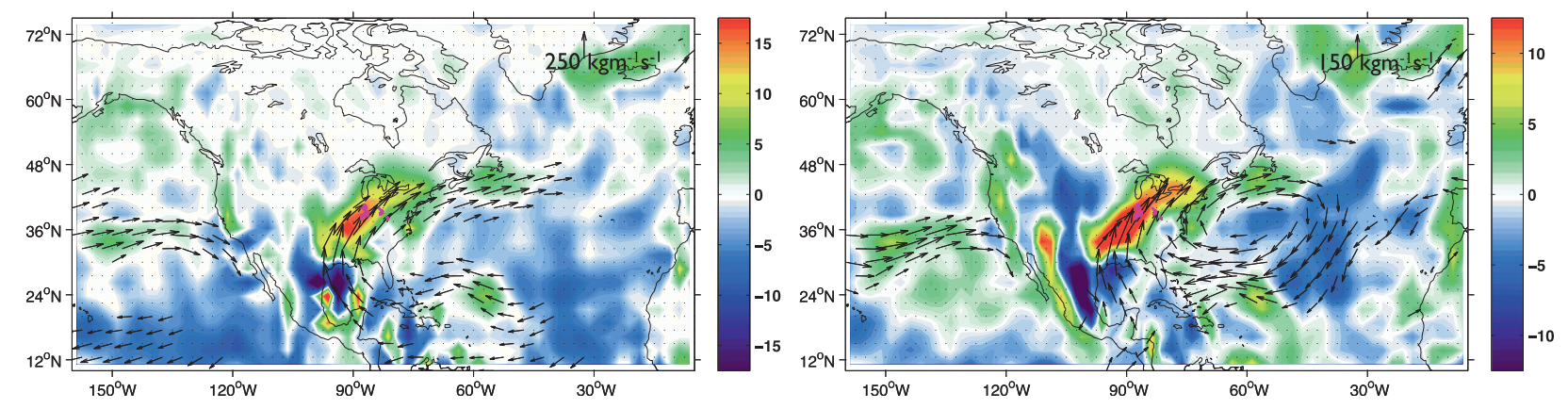

FIG. 3. (a) Vertically integrated surface- $600 \mathrm{hPa}$ moisture flux $\left(\mathrm{kg} \mathrm{m}^{-1} \mathrm{~s}^{-1}\right)$ (strongest $20 \%$ of values shown as arrows) and moisture convergence $\left(\mathrm{mm} \mathrm{day}^{-1}\right)$ (colors) for composite 20 extreme flood events observed in large drainage basins $\left(\right.$ size $\left.>10^{3} \mathrm{~km}^{2}\right)$ within the Ohio valley (basin outlines in dark pink) averaged over the nine days leading to the 10-yr flood. (b) As in (a) but for 18-27 Apr 2011. (left) Full field and (right) anomaly relative to a 1961-90 climatology.

$$
\begin{aligned}
Q_{\mathbf{v}}^{\prime}= & -\frac{1}{g}\left[\int_{p_{s}}^{600} \overline{\mathbf{v}} q^{\prime} d p+\int_{p_{s}}^{600} \mathbf{v}^{\prime} \bar{q} d p\right. \\
& \left.+\left(\int_{p_{s}}^{600} \mathbf{v}^{\prime} q^{\prime} d p-\int_{p_{s}}^{600} \overline{\mathbf{v}^{\prime} q^{\prime}} d p\right)\right],
\end{aligned}
$$

where $p_{s}$ is the surface pressure in millibars, $g$ the acceleration due to gravity, $\mathbf{v}$ the vector velocity, and $q$ is the specific humidity; the overbars indicate the 1961-90 climatological daily mean for the particular calendar date, and the primes denote the daily deviation from the climatological daily mean. Thus, the first rhs term is the component due to the climatological circulation advecting the anomalous moisture field (hereafter referred to as the humidity anomaly term), and the second term is the component due to the circulation anomaly advecting the climatological moisture field (hereafter the circulation anomaly term). The last two terms are the nonlinear cross terms contributing to the total convergence. They depict the anomalous advection due to the covariance between anomalies of both circulation components and specific humidity with respect to the climatological eddy covariance term (hereafter the eddy covariance anomaly term).

The results of this moisture transport decomposition and the associated convergence are shown in Figs. 4 and 5 and correspond to the composite of the 20 historical flood events (Fig. 4) and the April 2011 event (Fig. 5). The terms are averaged over the nine days leading to the flood and the flood dates itself (i.e., a 10-day average). The humidity anomaly term contribution is shown in the top panel of each figure, the circulation anomaly term in the middle panel, and the eddy covariance anomaly term contribution in the bottom panel. The total anomalous moisture transport and the total anomaly in transport convergence (shown in the left panels of Fig. 3) are clearly dominated by the circulation anomaly term (Figs. $4 \mathrm{~b}$ and 5b). In combination, these figures indicate that the averaged 10-day rainfall anomaly, and subsequently the floods themselves, were caused by a unique, persistent and strong atmospheric anticyclonic circulation anomaly east of the U.S. central Atlantic coast, which shifts the moisture transport from its typical path along the eastern foothills of the Rockies into the Mississippi/Ohio valley region. This eastward shift 
a) Humidity Anomaly Term

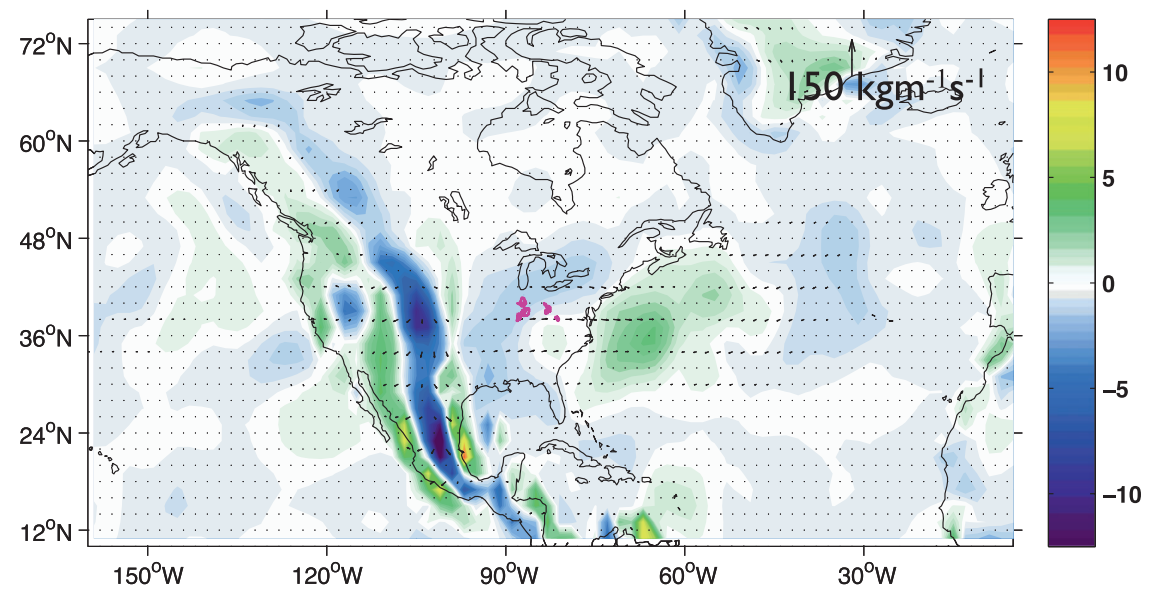

b) Circulation Anomaly Term



c) Eddy Covariance Anomaly Term

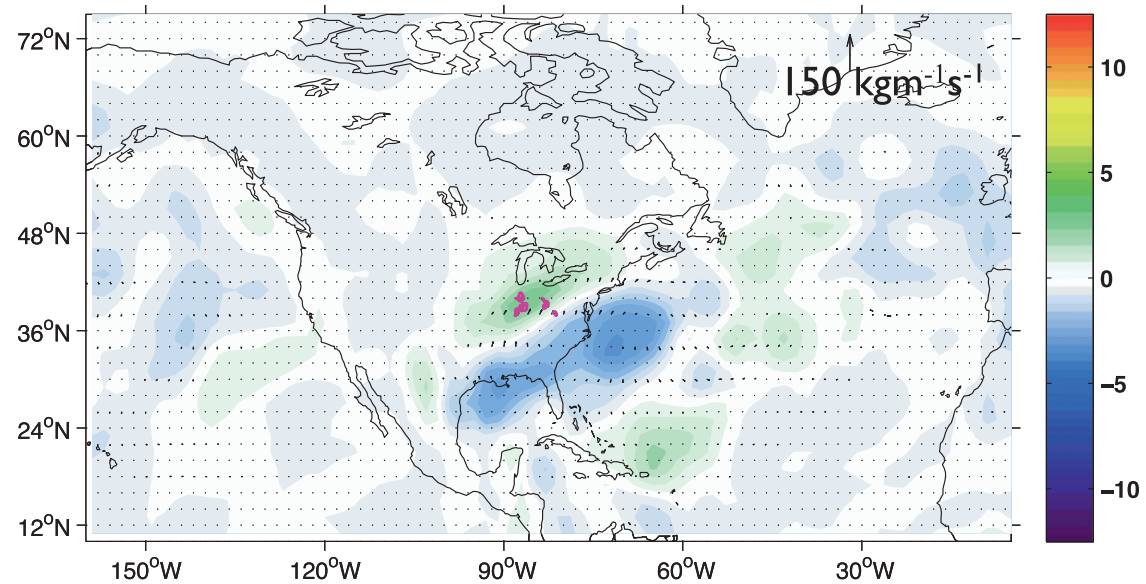

FIG. 4. Decomposition of the anomalous moisture transport for the 20 historical composites averaged over the nine days ( -9 to 0 ) leading to the flood (basin outlines in dark pink): moisture flux $\left(\mathrm{kg} \mathrm{m}^{-1} \mathrm{~s}^{-1}\right)$ (strongest $20 \%$ of values shown as arrows) and moisture convergence $\left(\mathrm{mm} \mathrm{day}^{-1}\right)$ (colors). (a) Humidity anomaly, (b) circulation anomaly, and (c) eddy covariance anomaly term. 
a) Humidity Anomaly Term

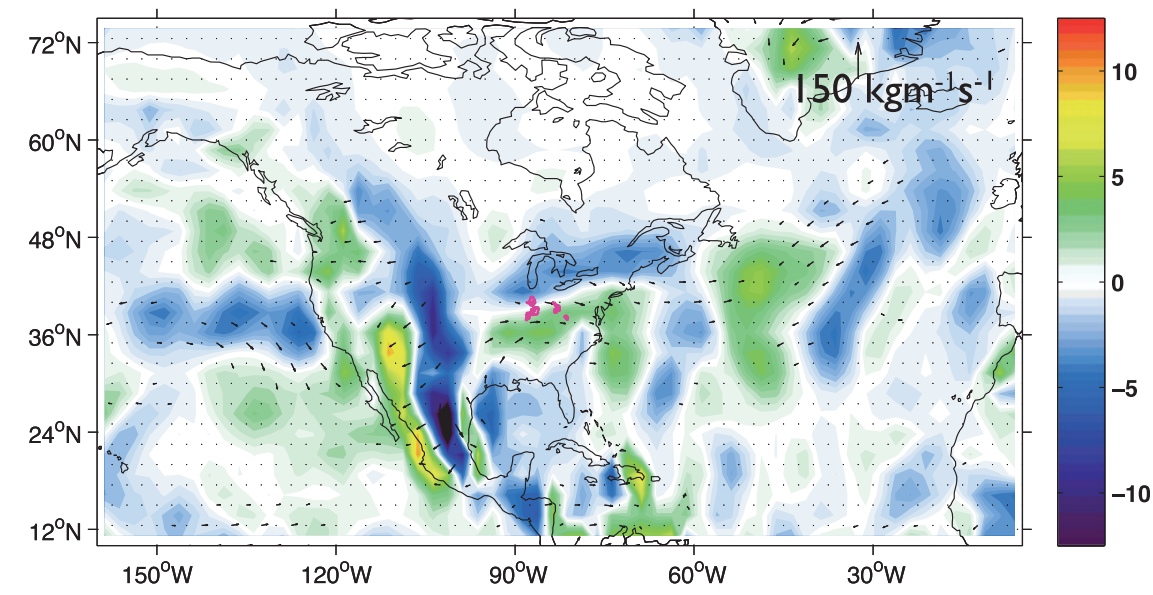

b) Circulation Anomaly Term



c) Eddy Covariance Anomaly Term

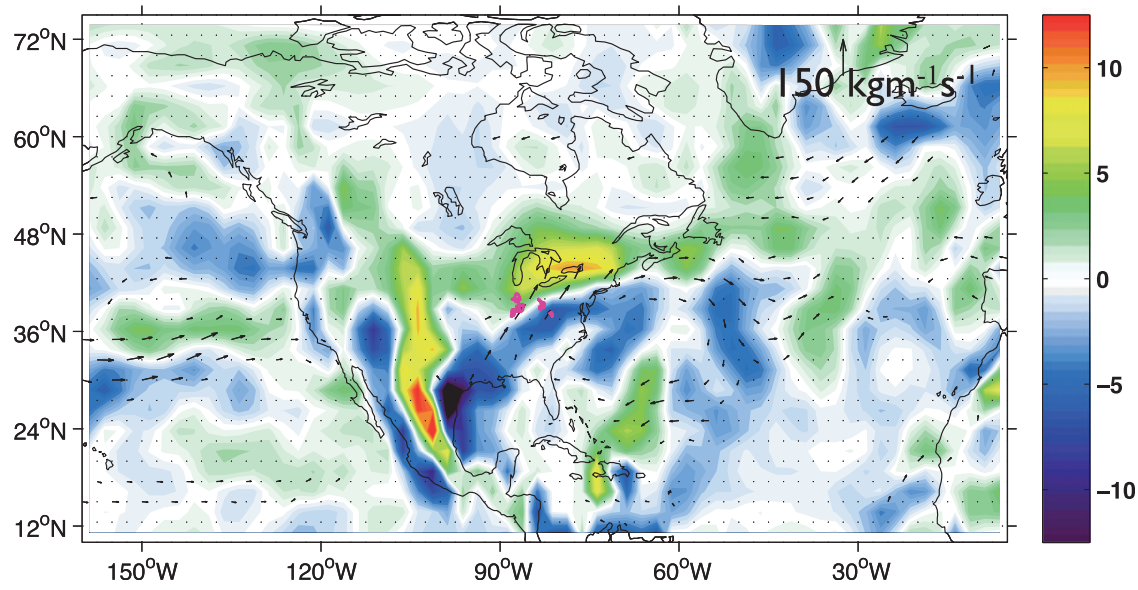

FIG. 5. As in Fig. 4 but for the April 2011 event.

weakens the climatological moisture convergence in the western high plains and generates anomalous moisture convergence in the east against the Appalachians. The humidity anomaly term (Figs. 4a and 5a) is a direct response to the change in circulation, which dries the atmosphere over the western plains and increases the moisture to the east. In general, the highfrequency transient eddies respond by acting to damp 
a) 25 Apr 2011

Humidity Anomaly Term

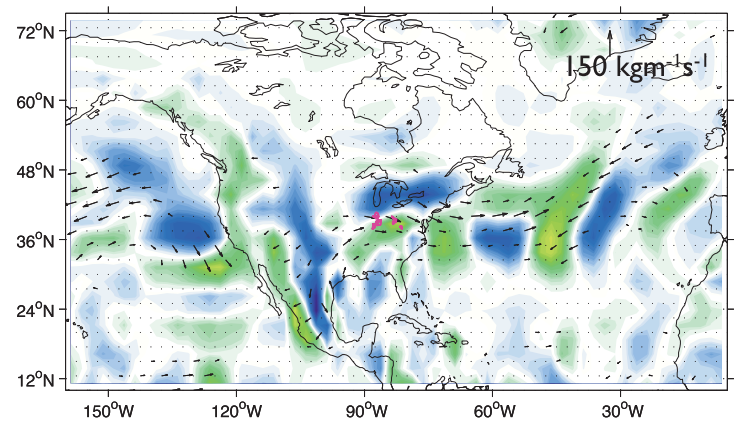

Circulation Anomaly Term
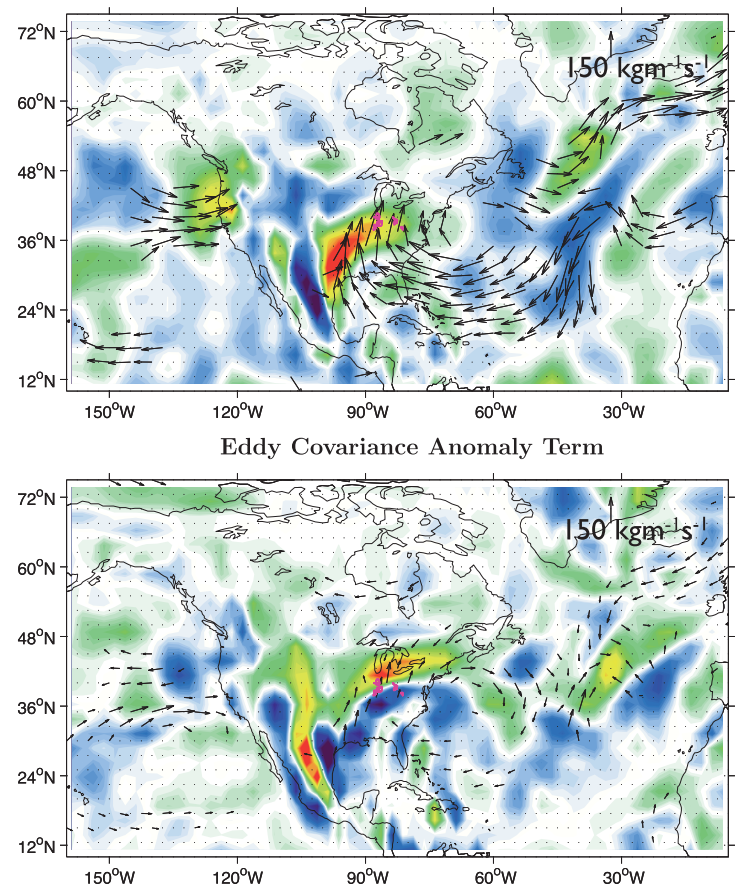

b) 27 Apr 2011

Humidity Anomaly Term
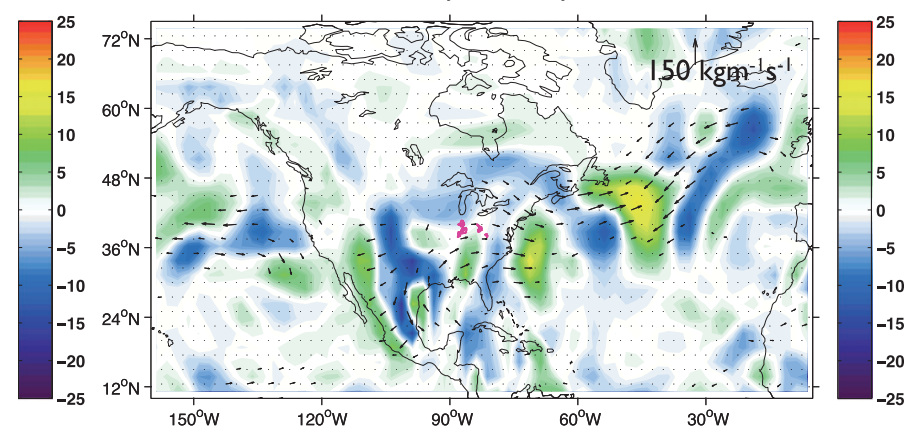

Circulation Anomaly Term
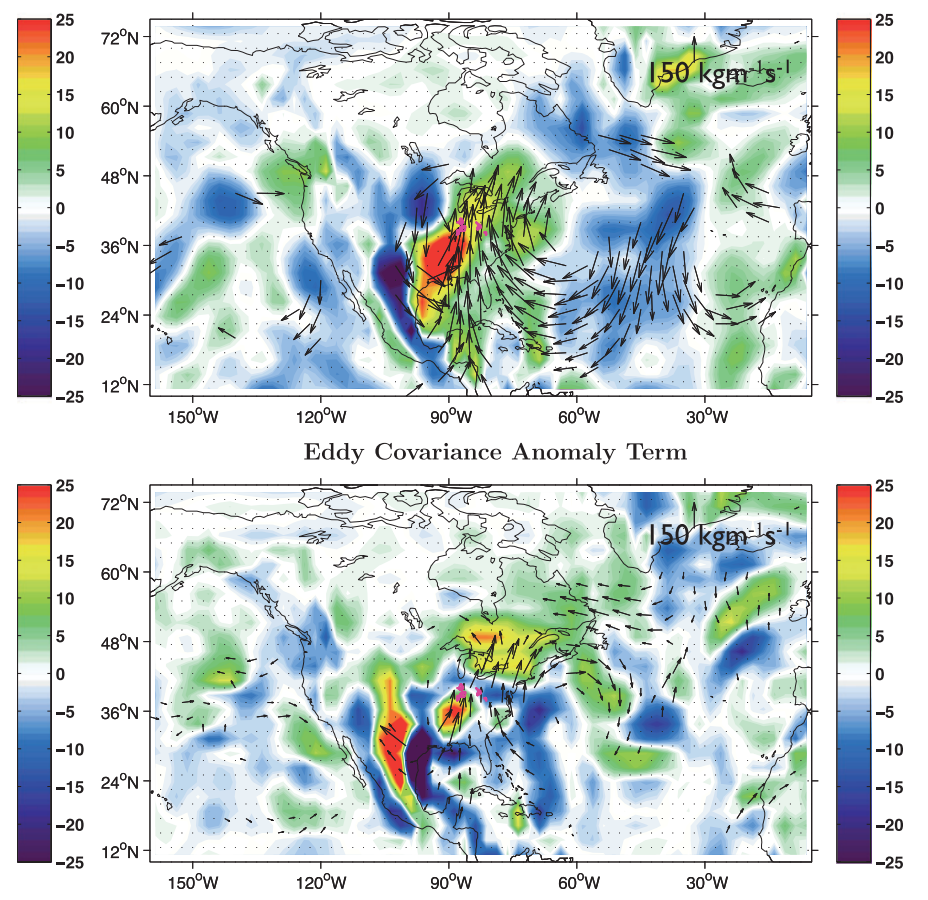

FIG. 6. Daily decomposition of the anomalous moisture transport for the April 2011 event (basin outlines in dark pink): moisture flux $\left(\mathrm{kg} \mathrm{m}^{-1} \mathrm{~s}^{-1}\right)$ (strongest $20 \%$ of values shown as arrows) and moisture convergence (mm day ${ }^{-1}$ ) (colors). (top) Humidity anomaly, (middle) circulation anomaly, and (bottom) eddy covariance anomaly term for (a) Day -2 (25 Apr 2011) and (b) day 0 (27 Apr 2011).

the anomaly due to the change in circulation (Figs. $4 \mathrm{c}$ and $5 \mathrm{c}$ ).

Individual daily components, as in Eq. (1), for selected days of the April 2011 event are shown in Fig. 6. These show that in the days immediately prior to the flood the eddy covariance term is stronger than when averaged over the prior 10 days (Fig. 5). The connection to the oceans is due primarily to the circulation anomaly alone, which is also responsible for channeling the oceanic moisture (supplied by full field circulation and moisture divergence; see Fig. 2, left side) into a corridor that leads to the flooded basins.

To further analyze the dynamical causes of the floods, we show in Fig. 7 maps of $700 \mathrm{hPa}$ geopotential height anomalies in contours and vertical pressure velocity in colors (blue/purple is upward motion) during day -9 , $-5,-3$, and -1 prior to the flood date for the composite of 20 historical events (left) and the April 2011 event (right). The dipole pattern of a significant positive geopotential high anomaly to the east of the flooded basins, together with a weaker low anomaly to the west, is established on day -9 and persists throughout the days leading to the flood event. Consistent with quasigeostrophic dynamics, there is northward and upward motion over the flooded basins. Flow around the high can be seen as the vectors of moisture flux in Fig. 3. Both historical and the April 2011 events show an intensification of the dipole between day -9 and day 0 and 

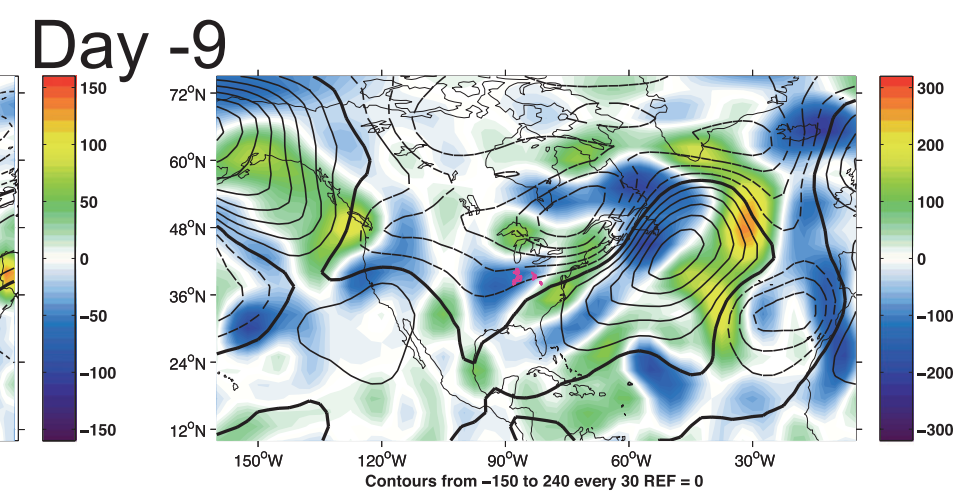

\section{Day -5}
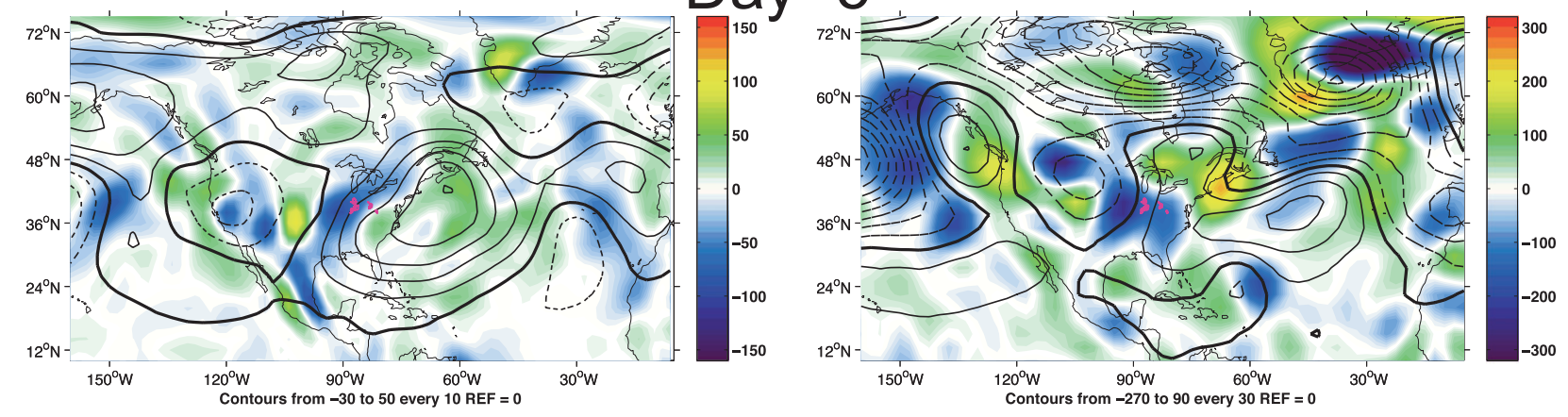

\section{Day -3}
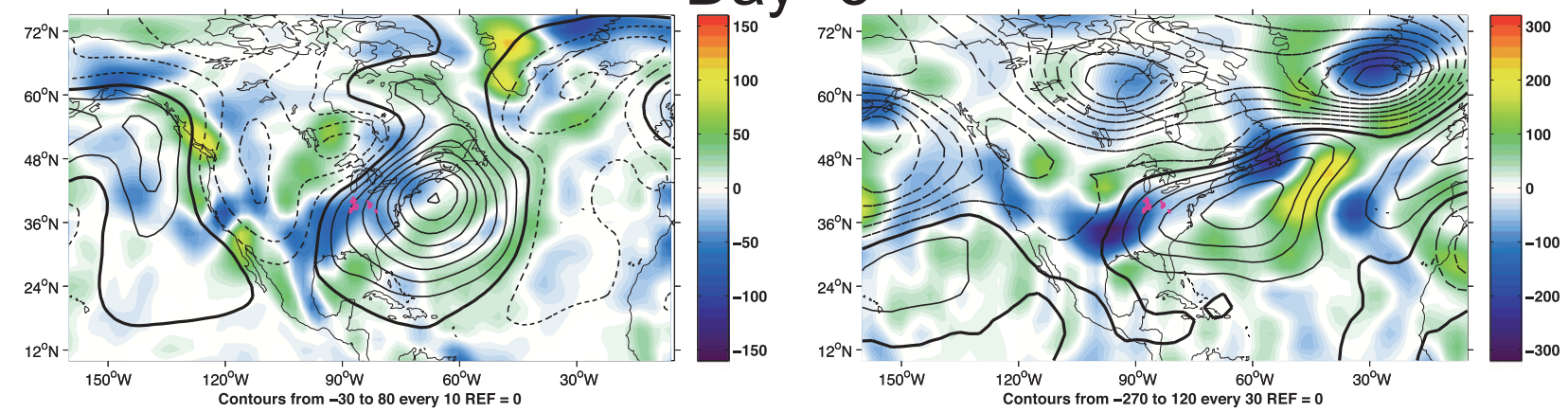

\section{Day -1}
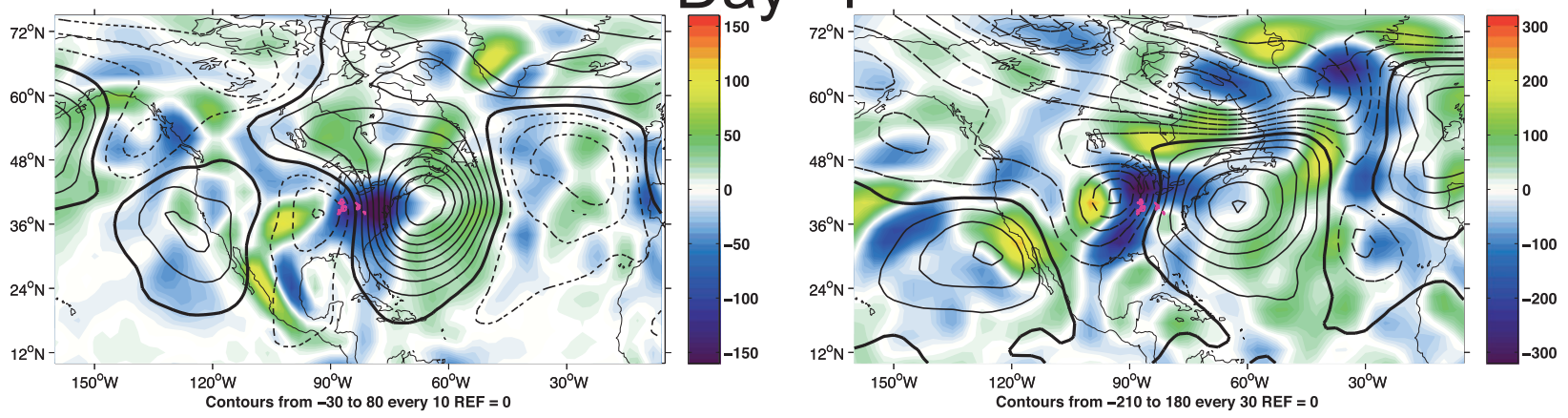

FIG. 7. (left) Average of 20 historical twentieth-century floods of large river basins in the Ohio valley (basin outlines in dark pink) on day -9 to -1 corresponding to (right) 18,22, 24, and 26 Apr 2011. Shown are 700-hPa geopotential height anomalies (m, contours) and vertical pressure velocity ( $\mathrm{hPa}$ day ${ }^{-1}$, colors: blue/purple is upward motion). Positive contours indicate anomalous positive heights (high pressure) and negative contours indicate anomalous negative heights (low pressure). 
a)

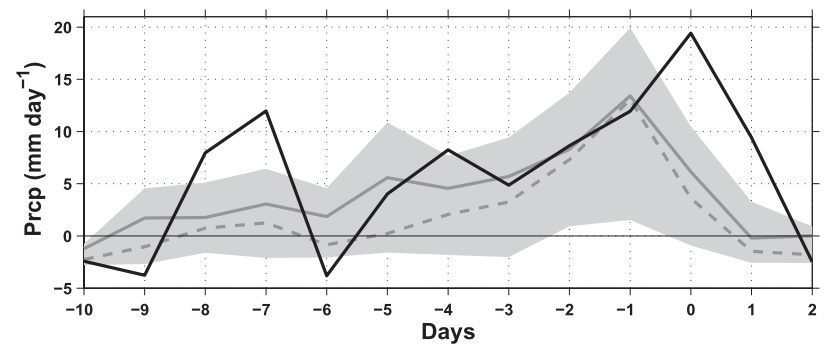

c)

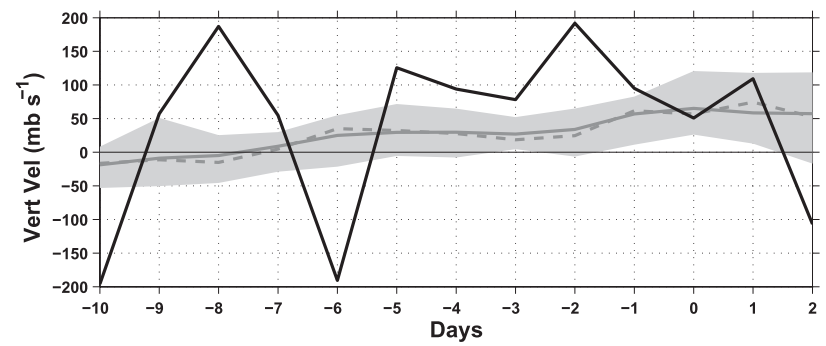

e)

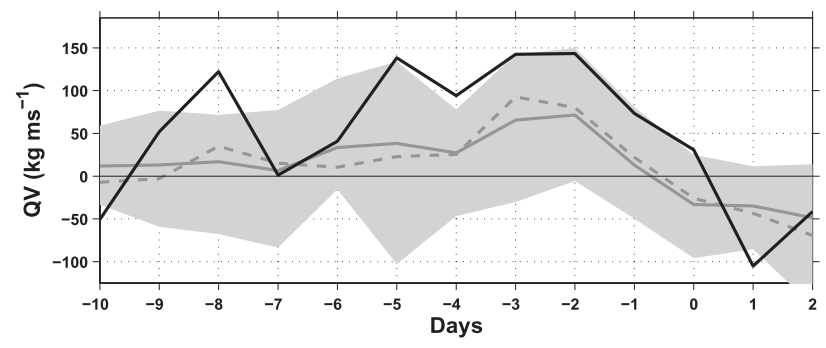

b)

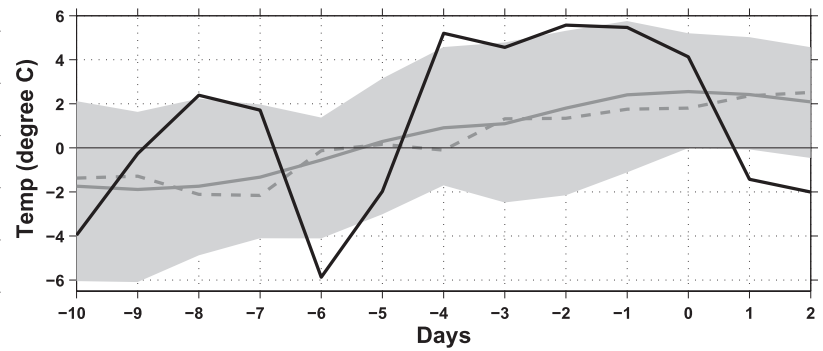

d)

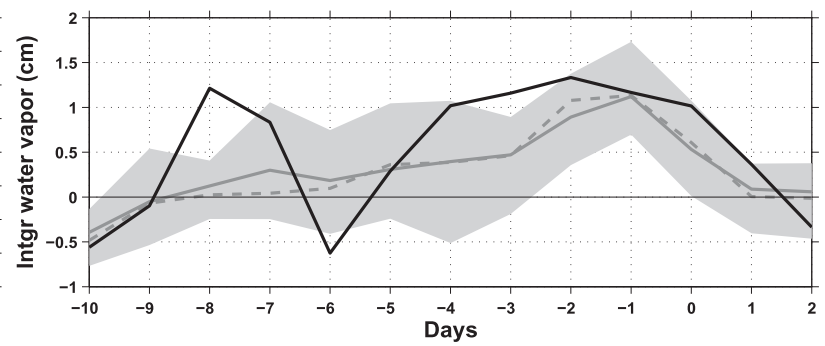

f)

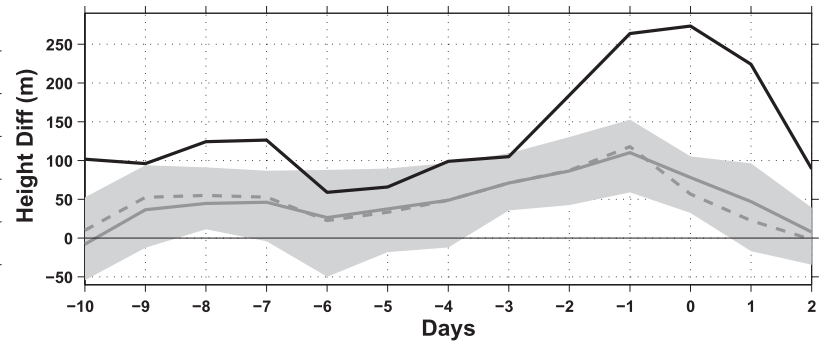

g)

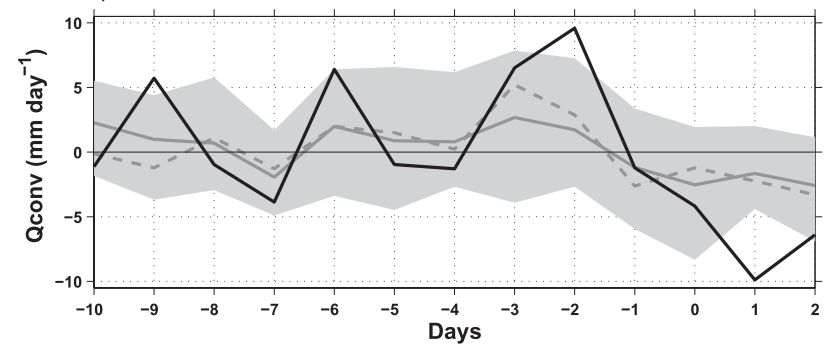

FIG. 8. Anomalous time series of variables averaged (a)-(d) over the Ohio River basin and (e),(g) between $28^{\circ}$ and $42^{\circ} \mathrm{N}, 100^{\circ}$ and $90^{\circ} \mathrm{W}$ and (f) height difference from day -10 to day 2 (flood is day 0 ). Shown are the 20-event composite mean (solid gray lines), median (dashed gray lines), and 25th to 75th percentile spread (gray shading), as well as the time series of the April 2011 event (black). (a) Precipitation, (b) near-surface air temperature, (c) 700-hPa vertical pressure velocity, (d) integrated water vapor, (e) surface-600 hPa vertically integrated meridional moisture flux, (f) difference between 700-hPa high and low height centers, and (g) surface-600 hPa vertically integrated moisture convergence.

transition from southwesterly to a more direct southerly flow into the basin on the days leading up to the flood.

To emphasize the persistent moisture transport and precipitation that are responsible for these flood events, we plot time series of anomalous precipitation, temperature, vertical velocity, integrated water vapor, northward water vapor transport $\left(Q_{\mathbf{v}}\right)$, and lower tropospheric and near-surface moisture convergence, all averaged over the flood basins (Figs. $8 \mathrm{a}-\mathrm{d}$ ) between $28^{\circ}$ and $42^{\circ} \mathrm{N}, 100^{\circ}$ and $90^{\circ} \mathrm{W}$ (Figs. $8 \mathrm{e}, \mathrm{g}$ ) from day -10 to day 2 , where day 0 corresponds to when the 10 -yr return threshold is exceeded. For both historical floods (gray lines and shading) and the April 2011 flood (black line), there is a positive trend in all variables until day 1 before the flood, 
a) MAM 20 Event Composite


b) 27 Apr 2011
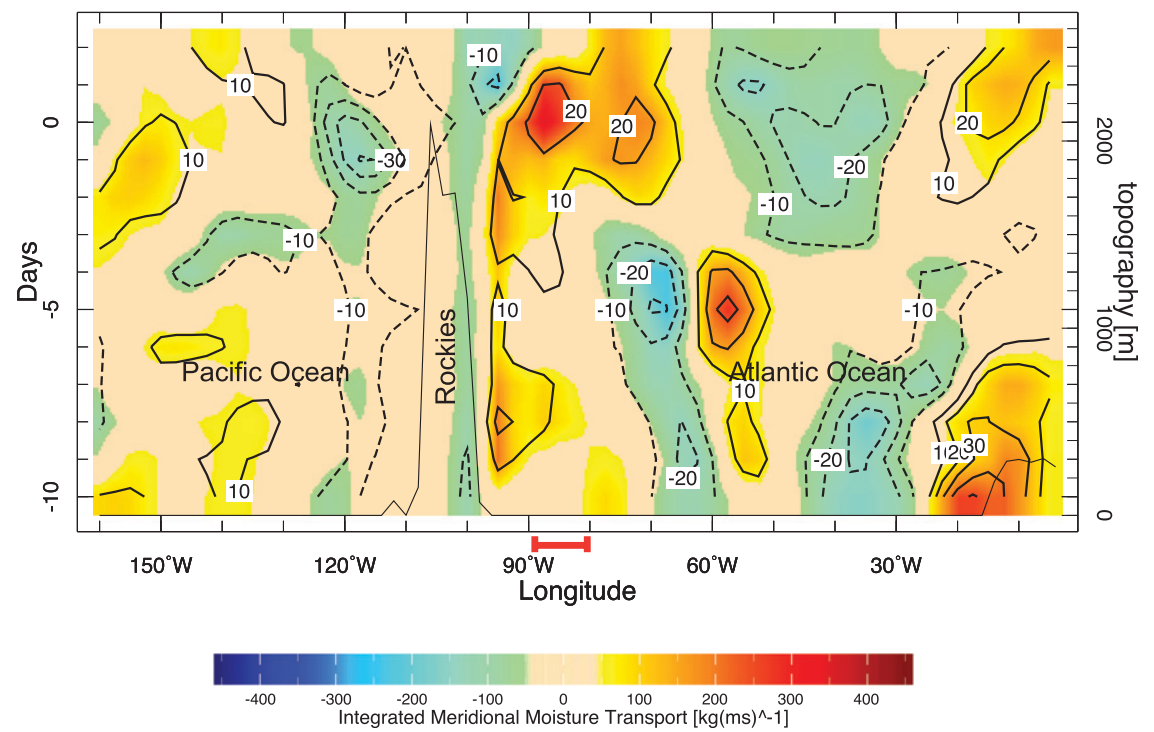

FIG. 9. (a) Composite of vertically integrated anomalous surface-600 hPa meridional winds (contours, $\mathrm{mm} \mathrm{day}^{-1}$ ) and moisture transport (colors, $\mathrm{kg} \mathrm{m}^{-1} \mathrm{~s}^{-1}$ ) along the latitude of $25^{\circ} \mathrm{N}$ for 20 extreme flood events observed in large drainage basins ( basin (day -10 to +2 ), plotted in days vs longitude where day 0 is the first day of the flood (the first day on which the streamflow reaches the 10-yr threshold). The cross section of the surface elevation is plotted for reference: note that for the contoured moisture transport the vertical axis marks the time referenced to the flood date. (b) As in (a) but for the 27 Apr 2011 flood event. Longitude range of Ohio subbasins marked in red on $x$ axis.

or on the day of the flood, and a steep drop thereafter. Note that, during the days leading to the April 2011 flood, there is a break in the upward trend between 7 and 6 days before the flood date. On those days the anomalous flow from the south at $700 \mathrm{hPa}$ shifts to the west briefly (not shown), taking the flood basin out of the area of high moisture transport convergence. Breaks in precipitation in the days leading up to a flood are standard and are associated with the movement of highfrequency synoptic events that move through the more permanent quasi-stationary dipole associated with the floods. The break does not appear to be significant when averaging 20 events owing to the stochastic nature of the underlying synoptic variability. The moisture transport, 
a) MAM 20 Event Composite
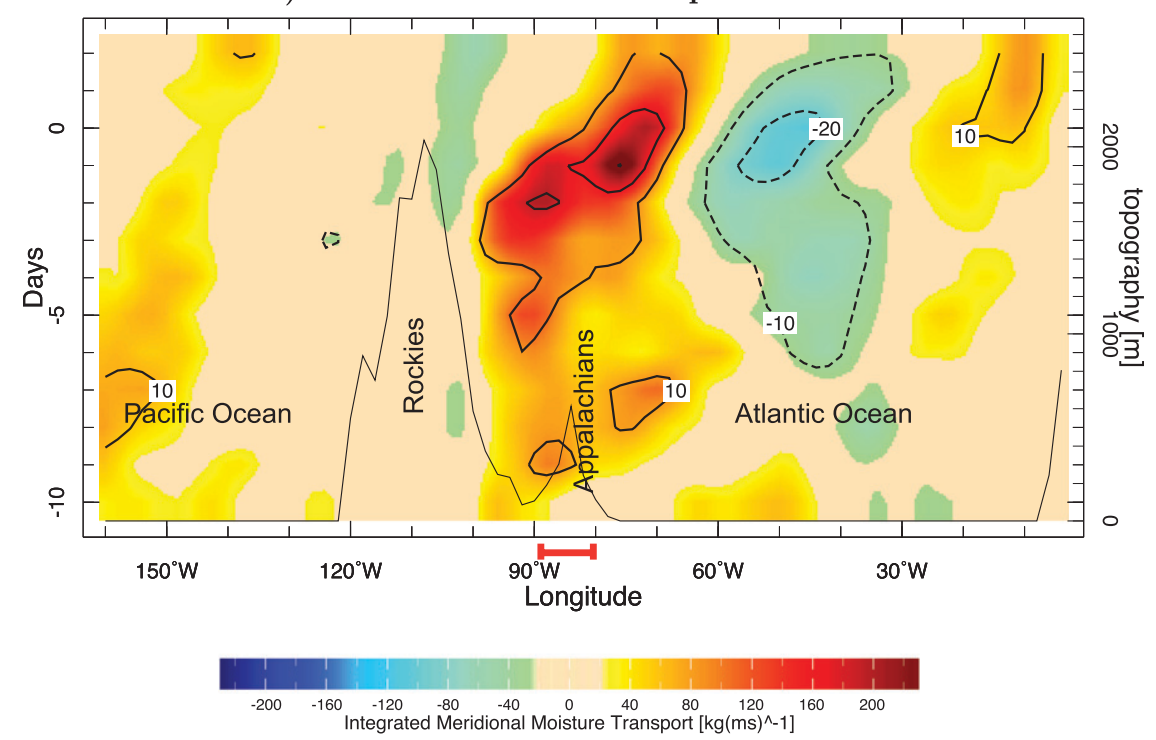

b) 27 Apr 2011
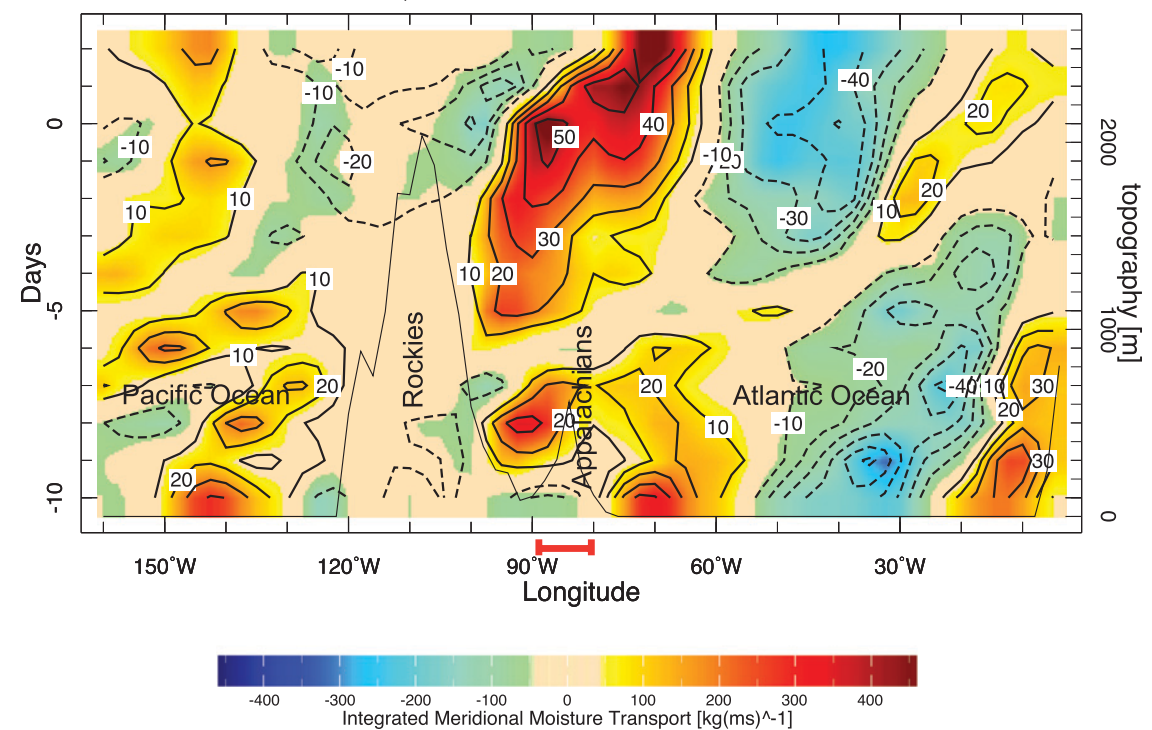

FIG. 10. As in Fig. 9 but along $35^{\circ} \mathrm{N}$.

convergence, and precipitation reach their maximum values a couple days prior to the flood. The delay of streamflow relative to precipitation may be due to the travel time of runoff water through the basin toward the gauging stations. Precipitation (Fig. 8a) is not exceptionally high on any one day, making the duration important for flood generation through surface soil saturation and subsequent production of overland flow. The basin averages of near-surface temperature, $700-\mathrm{hPa}$ vertical velocity, and integrated water vapor (Figs. 8b-d) show low-level warm, moist (and presumably buoyant) air in the region from day -9 to -7 and again from day -5 to the flood date. The narrow strip between $100^{\circ}$ and $90^{\circ} \mathrm{W}$ from the coast to the northern edge of the basin (Figs. 8e,g) was selected to show the Great Plains meridional moisture flux at $28^{\circ}$ and $42^{\circ} \mathrm{N}$. Figure $8 \mathrm{e}$ shows just the meridional part of the surface-600 hPa vertically integrated moisture transport $\left(Q_{\mathbf{v}}\right)$ and indicates the transport of warm moist air from the tropics. Also shown, in Fig. 8f, is the 700-hPa geopotential height difference between the centers of the anomalous high pressure cell to the east and the low pressure cell to the west of the Ohio basin (designated hereafter as the "dipole index"), defined based on the locations of these 


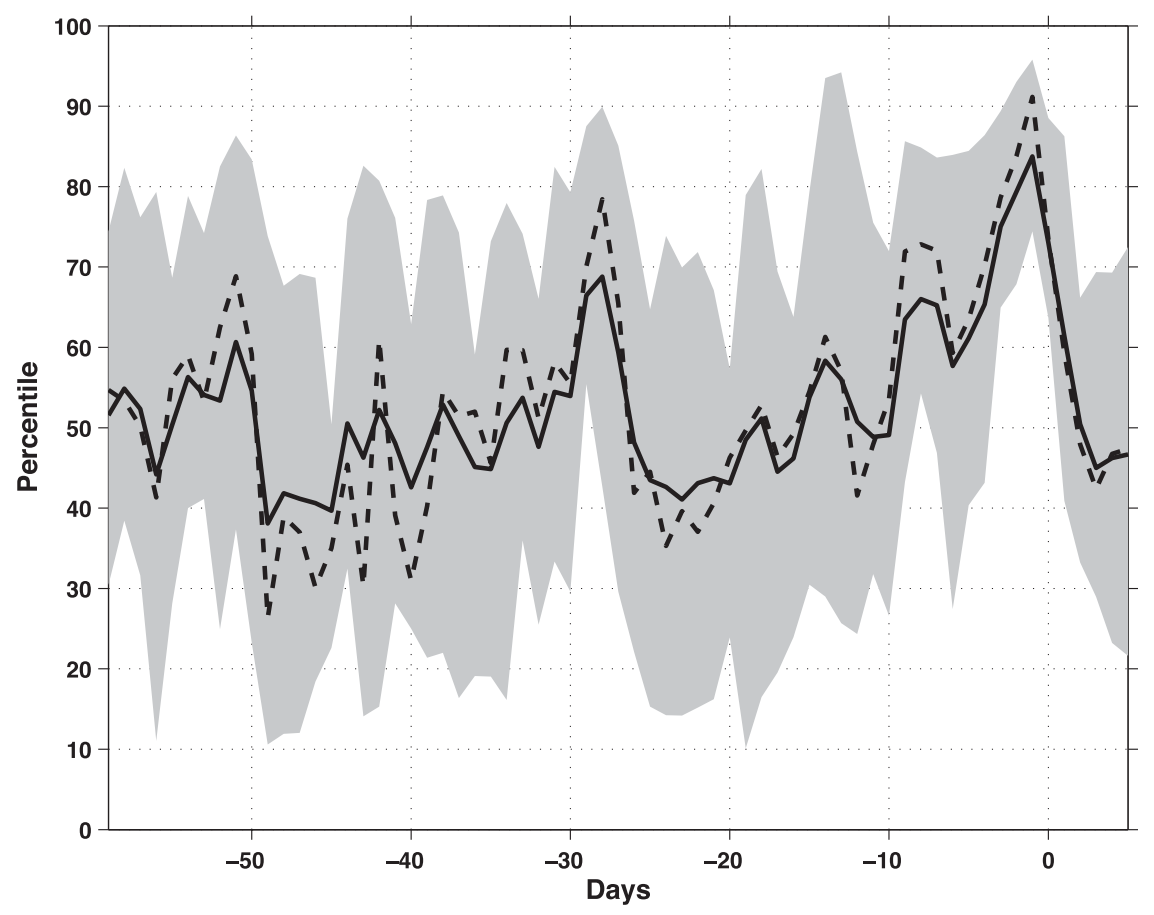

FIG. 11. Twenty-event composite mean (solid), median (dashed), and 25th to 75th percentile spread (gray shading) of day -59 to +5 (day 0 is the flood date) vs percentile relative to a January-May 1901-2008 climatology of the dipole index. Dipole index computed by taking the largest geopotential height of the $700-\mathrm{hPa}$ anomalous high pressure system in the Atlantic Ocean minus the smallest geopotential height of the anomalous low pressure system west of Ohio basin at their respective locations on day -1 .

centers on day -1 (see Fig. 7). This difference is proportional to the geostrophic flow in between. The persistently positive anomalous pressure gradient before the flood drives anomalous southerly flow into the region, as seen in both the historical and the April 2011 floods. Figure $8 \mathrm{~g}$ shows $600 \mathrm{hPa}$-surface convergence consistent with lifting of this air within the narrow northward-flowing moisture band from day -9 to -1 .

The eastern North American double maximum of poleward moisture transport identified by Knippertz and Wernli (2010) with channeling of moist flow between the Rocky and the Appalachian Mountain chains [the Great Plains meridional moisture flux (GP MMF) and a Gulf Stream flow meridional moisture flux (GS MMF)] to the east is visible in Figs. 9 and 10, which show a Hovmöller longitude-time plot of vertically integrated surface-600 $\mathrm{hPa}$ meridional wind (contours) and moisture transport (colors) anomalies along latitudes $25^{\circ} \mathrm{N}$ (Fig. 9) and $35^{\circ} \mathrm{N}$ (Fig. 10) for the composite historical flood events (Figs. 9a, 10a) and the April 2011 event (Figs. 9b, 10b). A cross section of the surface elevation is plotted for reference, but note that for the meridional winds and moisture transport the vertical axis marks time in days with reference to the flood date.
Maximum meridional transport at $25^{\circ} \mathrm{N}$ is located at day -4 to 0 for the historical composite, and there is a maximum at day 0 for the April 2011 event. Alignment of contours and colors shows the dominant control of the circulation anomaly on the total moisture transport anomaly. Moving from $25^{\circ}$ to $35^{\circ} \mathrm{N}$ there is an intensification of the wind and a corresponding intensification of the moisture transport. Maximum meridional transport at $35^{\circ} \mathrm{N}$ is located at day -2 for the historical composite GP MMF and day -1 for the GS MMF, and there is a double maximum at day -8 and day -1 through 0 of the GP MMF for the April 2011 event, with the GS MMF maximum a day later. Note that the anomalous moisture transport occurs at the eastern edge of the climatological springtime moisture transport path (Fig. 1), indicating a shift eastward due to the anomalous circulation patterns shown in Fig. 3. Therefore, the strong moisture transport into the Ohio basin is anomalous and is linked with the flood events exceeding the 10-yr return period.

Many of the definitions of the atmospheric river phenomenon set by Ralph and Dettinger (2011) with reference to the Pacific-North America sector are met in these cases of Ohio River basin floods-in particular, integrated water vapor greater than $2 \mathrm{~cm}$, wind speeds 
greater than $12.5 \mathrm{~m} \mathrm{~s}^{-1}$, and a narrow width of the moisture flow. The cross section in Fig. 10 shows that at $35^{\circ} \mathrm{N}$ the moisture flow is approximately $400-500 \mathrm{~km}$ across. The Ohio River moisture transport does not meet the length criterion of Ralph and Dettinger in a strict sense, but the distance from the Ohio River region to the Gulf of Mexico, Caribbean Sea, and the tropical Atlantic is naturally much smaller than to the Pacific Ocean, which can support long plumes of moisture from the central Pacific into the west coast of North America.

To explore the longer time scales associated with these flood events, the daily dipole index was computed and ranked for the months January-May and from 1901 to 2008. From this dataset the ranked values of the dipole index were composited day by day for day -59 to +5 for the historical 20 events (Fig. 11). The composited values (shown in percent) indicate that during the 65-day period the dipole values fluctuated, on average, between the 40th and 80th percentile of all historical daily values. Figure 11 shows a pattern that builds up to a successively higher percentile value up to the flood event. The figure suggests that there are two time scales in the buildup: a short one that roughly corresponds to the synoptic time scale of $\sim 10$ days and a longer one with an $\sim$ one-month time scale. The phase locking of these "cycles" with respect to the peak flood date indicates the role of baroclinic waves as well as possibly longer, subseasonal oscillations that may play a role in the leadup to these extreme floods. Kushnir and Wallace (1989) noted the existence of a waveguide for subseasonal oscillations extending from the eastern North Pacific, into North America, and toward the western North Atlantic with a structure similar to the patterns shown in Fig. 7. Possible origins for such variations are the tropical [Madden-Julian oscillation (MJO)] intraseasonal oscillation, which is known to impact North America (Higgins and Mo 1997), and 20-30-day midlatitude oscillations associated with the Rockies (mountain torques) that exhibit circulation structures similar to those of the dipolar pattern in Fig. 7 (Lott et al. 2004). Evidence that the MJO impacts weather types associated with Midwest flooding events is reported in Robertson et al. (2012, manuscript submitted to Geophys. Monogr.).

\section{$b$. The general role of circulation anomalies: $A$ comparison of the Ohio basin floods to those in Great Britain}

The Ohio basin floods are clearly caused by atmospheric circulation anomalies with a largely passive advection of water vapor that condenses out as rainfall over the basin. However, the Ohio basin floods are just one case study in a particular environment strongly a) Humidity Anomaly Term



b) Circulation Anomaly Term

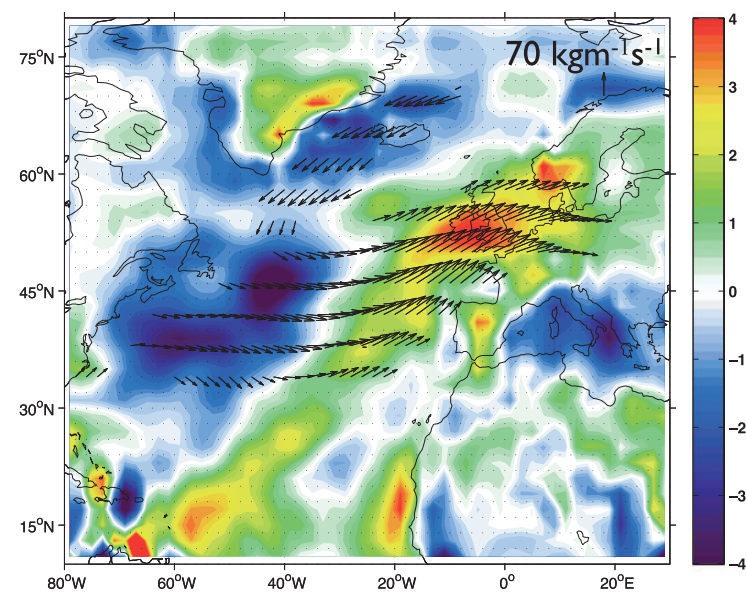

c) Eddy Covariance Anomaly Term

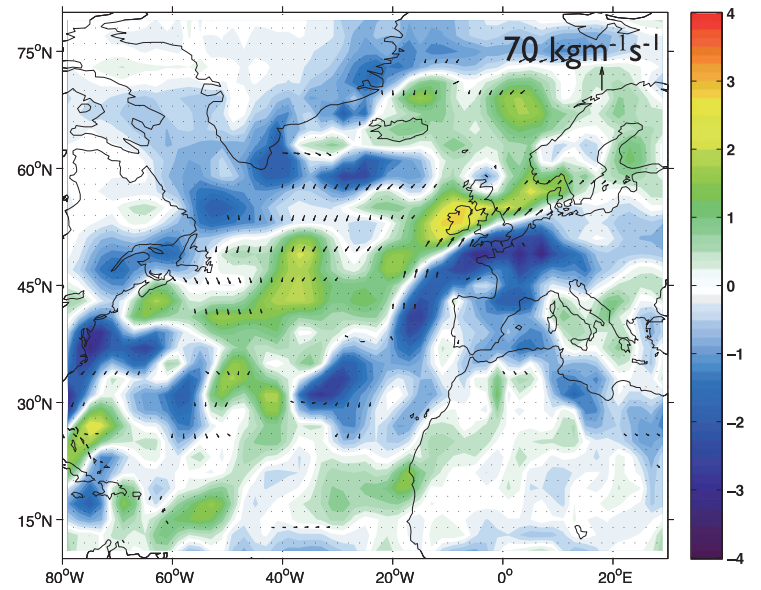

FIG. 12. Decomposition of the anomalous moisture transport for eight DJF flooding events on the river Eden at Temple Sowerby composite-averaged over the five days (day -5 to 0 ) leading up to the flood. Moisture flux $\left(\mathrm{kg} \mathrm{m}^{-1} \mathrm{~s}^{-1}\right.$ ) (strongest $20 \%$ of values shown as arrows) and moisture convergence $\left(\mathrm{mm} \mathrm{day}^{-1}\right)$ (colors): (a) humidity anomaly term, (b) circulation anomaly term, and (c) eddy covariance anomaly term. 
a) 1 Feb 2004

Humidity Anomaly Term

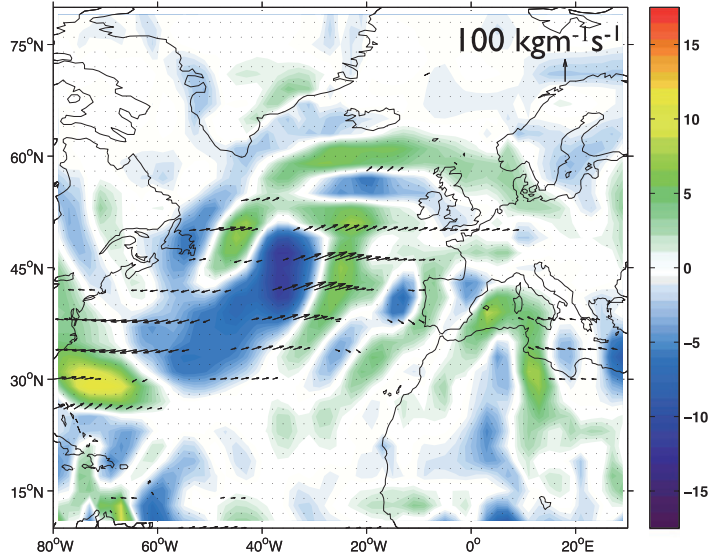

Circulation Anomaly Term

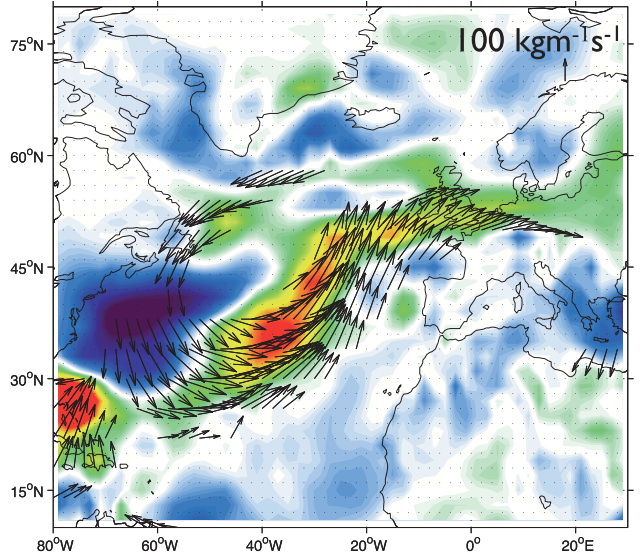

Eddy Covariance Anomaly Term

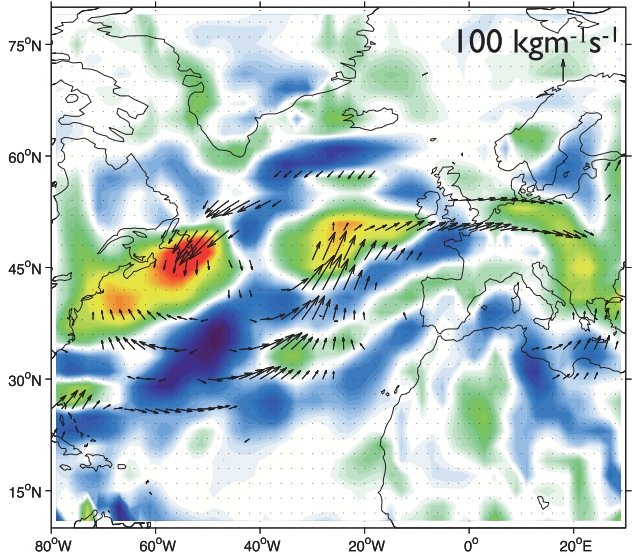

b) 31 Jan 2004

Humidity Anomaly Term



Circulation Anomaly Term

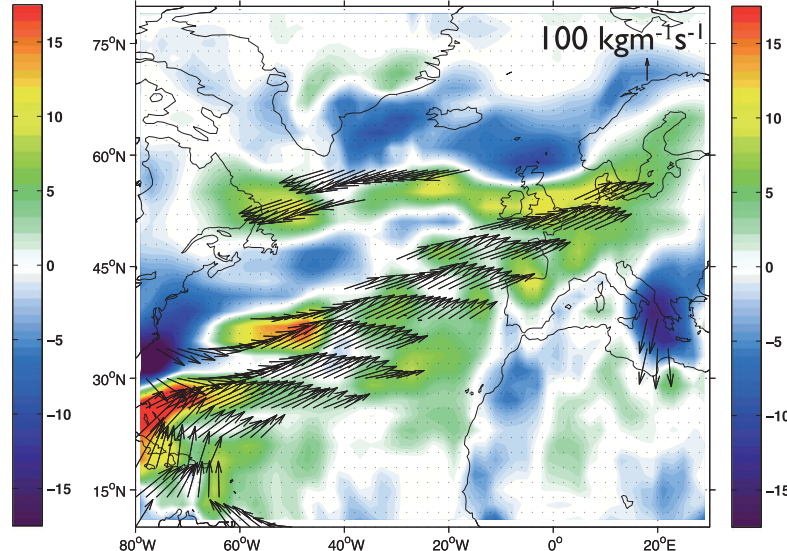

Eddy Covariance Anomaly Term

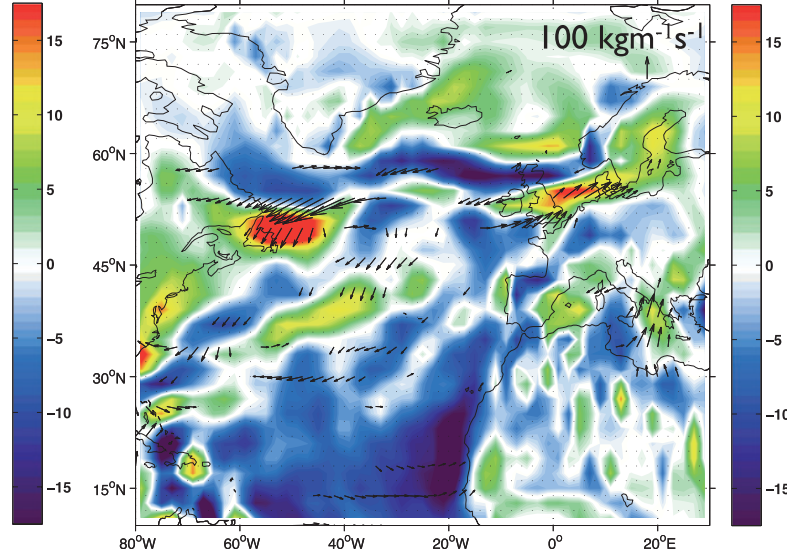

FIG. 13. Daily decomposition of the anomalous moisture transport for the 3 Feb 2004 flood event on the river Eden at Temple Sowerby: moisture flux $\left(\mathrm{kg} \mathrm{m}^{-1} \mathrm{~s}^{-1}\right)$ (strongest $20 \%$ of values shown as arrows) and moisture convergence $\left(\mathrm{mm} \mathrm{day}^{-1}\right.$ ) (colors). (top) Humidity anomaly term, (middle) circulation anomaly term, and (bottom) eddy covariance anomaly term for (a) day -2 (1 Feb 2004) and (b) day -3 (31 Jan 2004). 

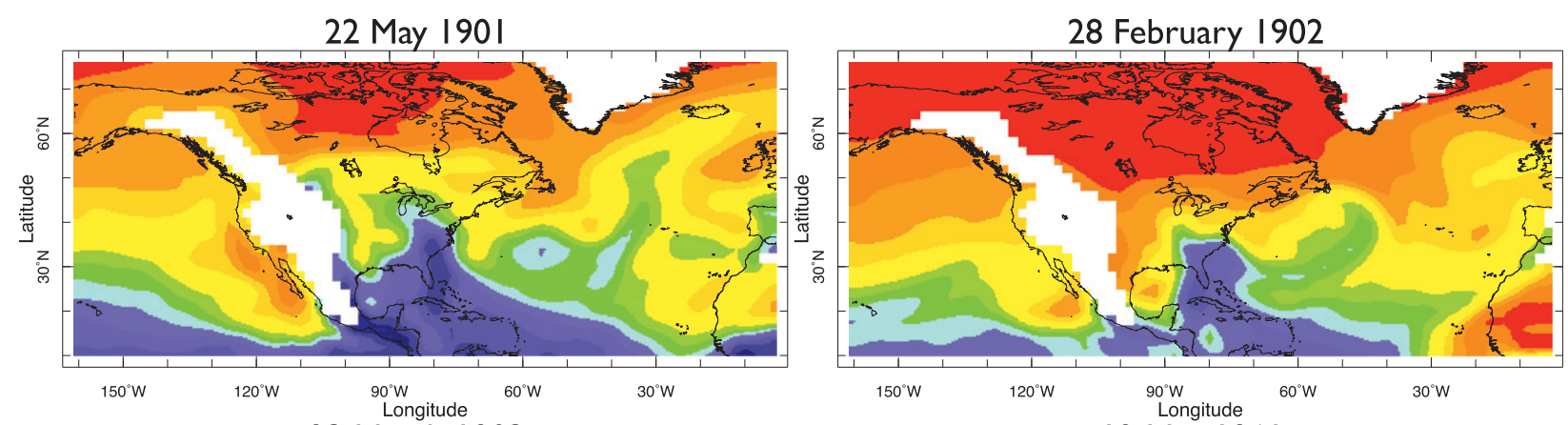

23 March 1903

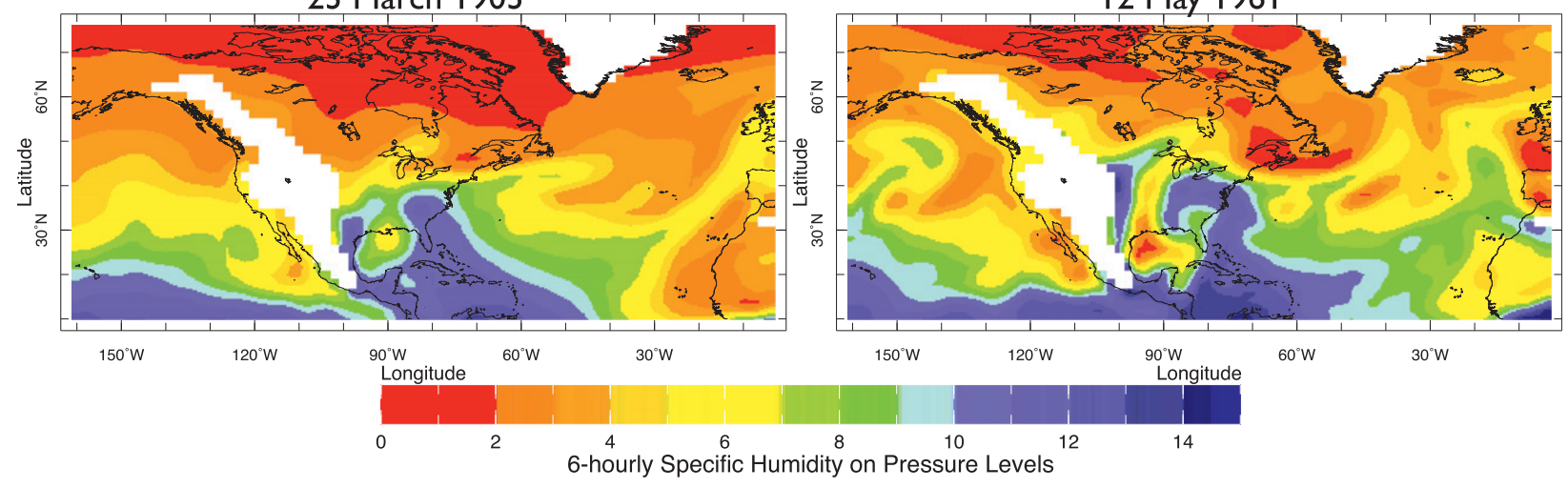

FIG. 14. The 20CR (Compo et al. 2011) 900-hPa specific humidity fields at 0900 UTC one day prior to four of the 20 historical Ohio basin flood dates.

influenced by the Bermuda high and topography of the Rockies and Appalachians. To assess whether the local characteristics of the dynamic circulation control are more general, we turn to a very different meteorological and climatological environment-that of Great Britain to the immediate east of the Atlantic Ocean with prevailing southwesterly winds. Lavers et al. (2011) identified winter atmospheric rivers originating in the subtropical Atlantic and flowing to Great Britain as responsible for severe flood events in a number of British river basins. One basin that they examined was that of the river Eden in northwest England where they identified 10 flood dates at Temple Sowerby. Eight of these flood events occurred prior to 2008 (7 January 2005, 3 January 1982, 31 January 1995, 28 December 2007, 23 February 1991, 3 February 2004, 5 December 2006, and 21 December 1985). For these events we conducted the same form of moisture transport decomposition as for the Ohio basin, taking the day -5 to day 0 average (the shorter averaging interval corresponding to the shorter duration of these events). The results in Fig. 12 are shown in a manner similar to Fig. 4. Over Great Britain, as in the cases of the Ohio basin, the total moisture transport anomaly and convergence are dominated by the circulation anomaly term (Fig. 12b), which depicts a pattern that shifts the moisture flux convergence from its normal location in the mid-Atlantic in the box $35^{\circ}-50^{\circ} \mathrm{N}, 60^{\circ}-$ $30^{\circ} \mathrm{W}$ (Fig. 1) northeastward toward the British Isles. The consequential moisture deficit created in the climatological convergence region and excess over the British Isles explain the moisture anomaly component of the flux and its convergence (Fig. 12a). Here, too, the eddy covariance term acts to damp the circulation anomalies. This indicates that the floods, as in the Ohio basin, were caused by persistent and strong circulation anomalies. Figure 13 shows the individual daily terms, as in Eq. (1), for day -2 and -3 for the Great Britain winter flood event of 3 February 2004. As in the Ohio River basin, the eddy covariance anomaly term is stronger near the basin on the daily, rather than the time-averaged, time scale, but the connection to the subtropics is due primarily to the circulation anomaly. The day -3 (Fig. 13b) circulation anomaly shows a striking direct link from the Caribbean to Great Britain.

The concentration of the 900-hPa specific humidity (as shown in Fig. 3 of Lavers et al. 2011) into filament-like, atmospheric river structures seems to apply in the Ohio River case as well. To show this we follow Lavers et al. (2011) and present the 900-hPa specific humidity fields one day prior to four of the 20 historical Ohio basin flood dates to illustrate the GS MMF (Fig. 14) and two days prior to illustrate the GP MMF (Fig. 15). These maps 
26 March 1913



I8 April 1940

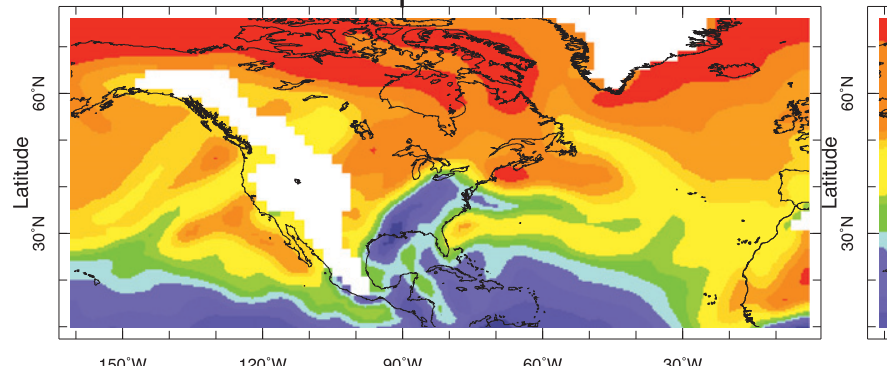

3 March 1934

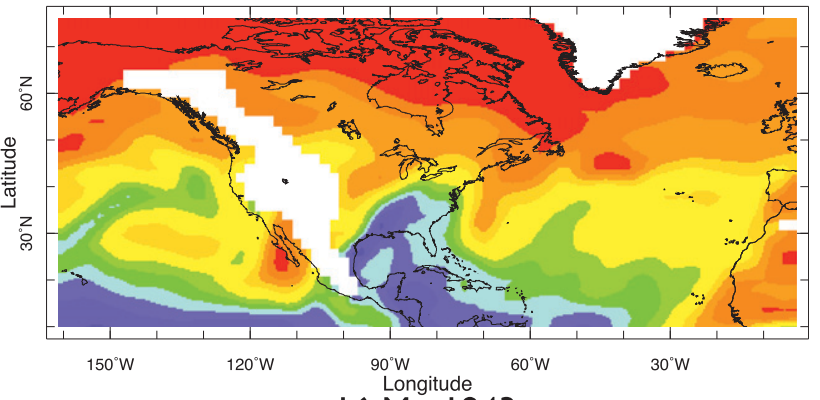

16 May 1943

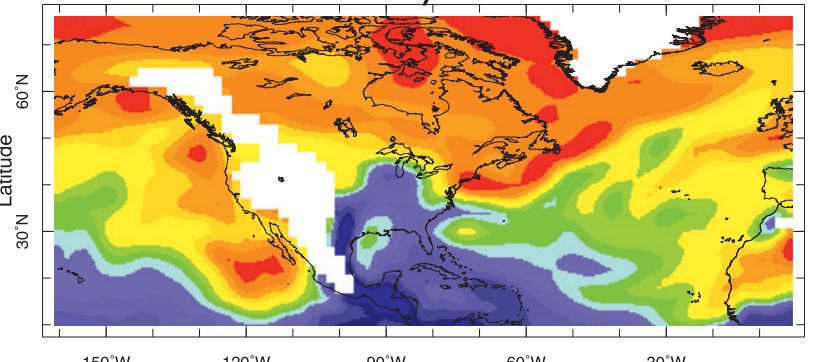

$150^{\circ} \mathrm{W}$

$90^{\circ} \mathrm{W}$

$60^{\circ} \mathrm{W}$

$30^{\circ} \mathrm{W}$

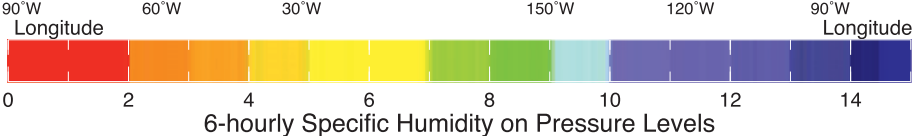

FIG. 15. As in Fig. 14 but for two days prior.

indeed show some similar filament-like structures for both GS and GP meridional moisture flux. The 16 May 1943 date is a representative example of a few dates on which both GS and GP MMF are present at day -2 with a small separation between the two. Surface-600 hPa integrated moisture convergence maps for these days (not shown) mirror the locations of the 900-hPa specific humidity maxima.

\section{Summary and conclusions}

We have identified important spatial and temporal features of the atmospheric circulation that lead to extreme spring floods in the Ohio River basin. This was done by compositing meteorological fields for 20 historical events and, separately, the more recent April 2011 event. Common to all of the floods is the low-level moisture divergence (source) in the tropical Atlantic, which is a climatological feature. Scattered anomalous sources are located in the northern Gulf of Mexico and are due to the anomalous steering of the climatological moisture supply. The anomalous low-level convergence (sink) above the flood basins is associated with a reproducible, persistent, anomalous circulation feature accompanied by strong upward vertical motion over the basin. The anomalous circulation is driving a strong southerly low-level flow of warm and moist air into the
Ohio basin, channeled from the Atlantic against the Appalachian mountain chains between anomalous quasistationary high and lowpressure cells to the east and west, respectively. This feature begins to develop as much as nine days before the flood date with stronger features established five days before the event. This anomalous pattern (Fig. 3, right panels) is an eastward shift of low-level convergence and moisture flux compared to the climatological pattern presented in Fig. 1. The "Maya Express" in Dirmeyer and Kinter (2009) is, in contrast, more akin to the intensification of the climatological pattern of moisture transport to a region west of the Ohio basin and associated with a strengthening, or westward shift, of the Bermuda high. Instead, during extreme Ohio basin floods, the anomalous high in the Atlantic is north of the Bermuda high and is paired in a dipole fashion with a low to the west of the basin on the western flank of the climatological high. The 20 flooding events show remarkable similarity in circulation pattern, and that the composite of the 20 events is still coherent after averaging shows the consistency of this pattern. The 2011 flood was also found to be typical of previous floods in the basin. This study is a sound confirmation of the Hirschboeck (1991) hypothesis that extreme floods in a given large basin and at a given season are due to typical circulation types and are not a collection of random, unrelated events. 
Decomposition of the anomalous total moisture transport associated with Ohio basin floods into the transport of climatological moisture by the anomalous atmospheric wind circulation and transport of anomalous specific humidity by the climatological circulation confirms that these floods are governed by the anomalous circulation. Similar decomposition of winter atmospheric rivers impacting the river Eden at Temple Sowerby in northwest England shows that these also are caused by atmospheric circulation anomalies, though those are different than in the Ohio case. This makes it clear that-for these very different meteorological, climatological, and geographical environments-the strong moisture fluxes and the floods that they cause are fundamentally anomalous dynamical features of the atmospheric circulation (and not of the moisture field) and may be due to quasigeostrophic circulations intensifying gradients along a front, as described by Hoskins and Bretherton (1972). This "atmospheric channeling" of the moisture field is referred to as an atmospheric river.

The persistent meteorological patterns associated with the Ohio floods suggest the possibility that globalscale circulation driven by specific nonlocal dynamics may contribute to them. For example, the long-lasting La Niña climate pattern, persisting into the spring of 2011, could have contributed to the basic large-scale ingredients of the event with a strong cold trough over Canada and warm ridge over the U. S. Southwest and Atlantic Ocean. The daily circulation types associated with Ohio basin flooding events were found to be significantly more prevalent during La Niña events by Robertson et al. (2012, manuscript submitted to Geophys. Monogr.). However the March-May El Niño 3.4 index averaged for the years of the 20 historical events is only trivially negative $\left(-0.02^{\circ} \mathrm{C}\right)$, so the relationship with ENSO is weak in general.

Interestingly, Ohio River floods were more common in the early and mid twentieth century than in recent decades. Whether the 2011 event heralds a return of more frequent flooding, or this is merely a result of random variability, requires more research into how the frequency and intensity of the synoptic events responsible for floods varies on decadal time scales and how they are potentially influenced by large-scale modes of low frequency climate variability.

Acknowledgments. Our work was supported by NOAA Grants NA10OAR4310159, NA10OAR4320137, and NA10OAR4310137 (Global Decadal Hydroclimate Variability and Change). Analysis was made possible by 20 th Century Reanalysis and the USGS HCDN streamflow data set. We thank two anonymous reviewers for their constructive advice and guidance.

\section{REFERENCES}

Barriopedro, D., E. M. Fischer, J. Luterbacher, R. M. Trigo, and R. García-Herrera, 2011: The hot summer of 2010: Redrawing the temperature record map of Europe. Science, 332, 220-224.

Compo, G. P., and Coauthors, 2011: The Twentieth Century Reanalysis project. Quart. J. Roy. Meteor. Soc., 137, 1-28.

Dettinger, M., 2011: Climate change, atmospheric rivers, and floods in California-A multimodel analysis of storm frequency and magnitude changes. J. Amer. Water Resour. Assoc., 47, 514523.

, F. M. Ralph, T. Das, P. J. Neiman, and D. Cayan, 2011: Atmospheric rivers, floods, and the water resources of California. Water, 3, 455-478.

Dirmeyer, P. A., and J. L. Kinter III, 2009: The "Maya Express": Floods in the U.S. Midwest. Eos, Trans. Amer. Geophys. Union, 90, 101, doi:10.1029/2009EO120001.

$\longrightarrow$, and — 2010: Floods over the U.S. Midwest: A regional water cycle perspective. J. Hydrometeor., 11, 1172-1181.

Dole, R., and Coauthors, 2011: Was there a basis for anticipating the 2010 Russian heat wave? Geophys. Res. Lett., 38, L06702, doi:10.1029/2010GL046582.

Emanuel, K., 2010: Tropical cyclone activity downscaled from NOAA-CIRES reanalysis, 1908-1958. J. Adv. Model. Earth Syst., 2, 1, doi:10.3894/JAMES.2010.2.1.

Federal Interagency Floodplain Management Task Force, 1992: Floodplain management in the United States: An assessment report. Volume 1: Summary. FEMA Publ. FIA-17, Federal Emergency Management Agency, Washington, DC, 69 pp. [Available online at http://www.fema.gov/library/viewRecord. do?id=1416.]

Higgins, R. W., and K. C. Mo, 1997: Persistent North Pacific circulation anomalies and the tropical intraseasonal oscillation. J. Climate, 10, 223-244.

Hirschboeck, K. K., 1991: Climates and floods. National water summary 1988-89-Floods and droughts: Hydrologic perspectives on water issues, R. W. Paulson et al., Eds., USGS Water-Supply Paper 2375, 67-88. [Available online at http:// pubs.usgs.gov/wsp/2375/report.pdf.]

Hoskins, B. J., and F. P. Bretherton, 1972: Atmospheric frontogenesis models: Mathematical formulation and solution. J. Atmos. Sci., 29, 11-37.

Kistler, R., and Coauthors, 2001: The NCEP-NCAR 50-Year Reanalysis: Monthly means CD-ROM and documentation. Bull. Amer. Meteor. Soc., 82, 247-268.

Knippertz, P., and H. Wernli, 2010: A Lagrangian climatology of tropical moisture exports to the Northern Hemispheric extratropics. J. Climate, 23, 987-1003.

Kushnir, Y., and J. M. Wallace, 1989: Low-frequency variability in the Northern Hemisphere winter: Geographical distribution, structure and time-scale dependence. J. Atmos. Sci., 46, 31223142 .

Lavers, D. A., R. P. Allan, E. F. Wood, G. Villarini, D. J. Brayshaw, and A. J. Wade, 2011: Winter floods in Britain are connected to atmospheric rivers. Geophys. Res. Lett., 38, L23803, doi:10.1029/2011GL049783.

Lott, F., A. W. Robertson, and M. Ghil, 2004: Mountain torques and Northern Hemisphere low-frequency variability. Part II: Regional aspects. J. Atmos. Sci., 61, 1272-1283.

Moore, B. J., P. J. Neiman, F. M. Ralph, and F. E. Barthold, 2012: Physical processes associated with heavy flooding rainfall in Nashville, Tennessee, and vicinity during 1-2 May 2010: The 
role of an atmospheric river and mesoscale convective systems. Mon. Wea. Rev., 140, 358-378.

Neiman, P. J., L. J. Schick, F. M. Ralph, M. Hughes, and G. A. Wick, 2011: Flooding in western Washington: The connection to atmospheric rivers. J. Hydrometeor., 12, 1337-1358.

Ockenden, M. C., and N. A. Chappell, 2011: Identification of the dominate runoff pathways from the data-based mechanistic modelling of nested catchments in the temperate UK. J. Hydrol., 402, 71-79.

Perry, C. A., 2000: Significant floods in the United States during the 20th century-USGS measures a century of floods. USGS Fact Sheet 024-00, 4 pp. [Available online at http://ks.water. usgs.gov/pubs/fact-sheets/fs.024-00.pdf.]

Ralph, F. M., and M. D. Dettinger, 2011: Storms, floods, and the science of atmospheric rivers. Eos, Trans. Amer. Geophys. Union, 92, 265, doi:10.1029/2011EO320001.

, P. J. Neiman, G. A. Wick, S. I. Gutman, M. D. Dettinger, D. R. Cayan, and A. B. White, 2006: Flooding on California's
Russian River: Role of atmospheric rivers. Geophys. Res. Lett., 33, L13801, doi:10.1029/2006GL026689.

Truchelut, R. E., and R. E. Hart, 2011: Quantifying the possible existence of undocumented Atlantic warm-core cyclones in NOAA/CIRES 20th Century Reanalysis data. Geophys. Res. Lett., 38, L08811, doi:10.1029/2011GL046756.

Vose, R. S., R. L. Schmoyer, P. M. Steurer, T. C. Peterson, R. Heim, T. R. Karl, and J. K. Eischeid, 1992: The Global Historical Climatology Network: Long-term monthly temperature, precipitation, sea level pressure, and station pressure data. ORNL/CDIAC-53, NDP-041, Carbon Dioxide Information Analysis Center, Oak Ridge National Laboratory, Oak Ridge, TN, 324 pp. [Available online at http://cdiac. ornl.gov/ftp/ndp041/ndp041.pdf.]

Zhu, Y., and R. E. Newell, 1994: Atmospheric rivers and bombs. Geophys. Res. Lett., 21, 1999-2002. and - 1998: A proposed algorithm for moisture fluxes from atmospheric rivers. Mon. Wea. Rev., 126, 725-735. 